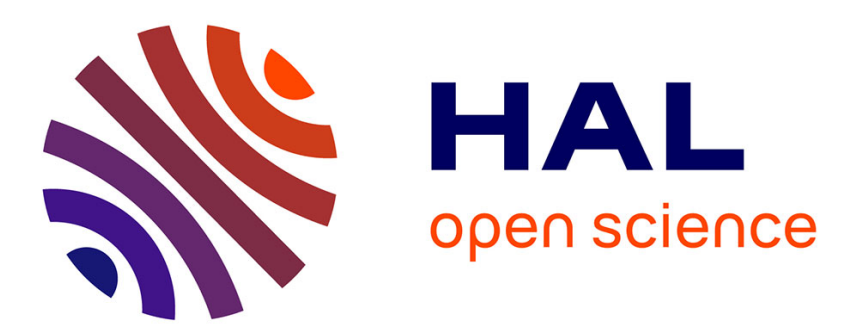

\title{
The end-Cretaceous in the southwestern Tethys (Elles, Tunisia): orbital calibration of paleoenvironmental events before the mass extinction
}

Nicolas Thibault, Bruno Galbrun, Silvia Gardin, Fabrice Minoletti, Laurence Le Callonnec

\section{To cite this version:}

Nicolas Thibault, Bruno Galbrun, Silvia Gardin, Fabrice Minoletti, Laurence Le Callonnec. The end-Cretaceous in the southwestern Tethys (Elles, Tunisia): orbital calibration of paleoenvironmental events before the mass extinction. International Journal of Earth Sciences, 2015, pp.1-25. 10.1007/s00531-015-1192-0 . hal-01189699

\section{HAL Id: hal-01189699 \\ https://hal.science/hal-01189699}

Submitted on 1 Sep 2015

HAL is a multi-disciplinary open access archive for the deposit and dissemination of scientific research documents, whether they are published or not. The documents may come from teaching and research institutions in France or abroad, or from public or private research centers.
L'archive ouverte pluridisciplinaire HAL, est destinée au dépôt et à la diffusion de documents scientifiques de niveau recherche, publiés ou non, émanant des établissements d'enseignement et de recherche français ou étrangers, des laboratoires publics ou privés. 


\title{
The end-Cretaceous in the southwestern Tethys (Elles, Tunisia): orbital calibration of paleoenvironmental events before the mass extinction
}

\author{
Nicolas Thibault ${ }^{1}$, Bruno Galbrun ${ }^{2}$, Silvia Gardin ${ }^{3}$, \\ Fabrice Minoletti ${ }^{2}$ and Laurence Le Callonnec ${ }^{2}$
}

(1) IGN, University of Copenhagen, Øster Voldgade 10, 1350 Copenhagen K, Denmark

(2) Institut des Sciences de la Terre Paris (ISTeP), UMR 7193, UPMC Univ Paris 06, Sorbonne Universités, 75005 Paris, France

(3) Centre de Recherche sur la Paléobiodiversité et les Paléoenvironnements, UMR 7072, UPMC Univ

Paris 06, Sorbonne Universités, 75005 Paris, France

Nicolas Thibault Email: nt@ign.ku.dk

\begin{abstract}
An integrated study of magnetic mass susceptibility (MS), bulk stable isotopes and calcareous nannofossil paleoecological changes is undertaken on the late Maastrichtian of the Elles section, Tunisia, spanning the last ca. 1 Myr of the Cretaceous. A cyclostratigraphic analysis reveals the presence of Milankovitch frequencies and is used for proposal of two distinct orbital age models and to provide ages of important stratigraphic horizons, relative to the age of the Cretaceous-Paleogene boundary (K-PgB). Principal component analysis (PCA) performed on the nannofossil assemblage reveal two main factors, PCA1, mostly representing fluctuations of $D$. rotatorius, $P$. stoveri, Lithraphidites spp., Retecapsa spp., Staurolithites spp., Micula spp., and PCA2, mostly representing fluctuations of $A$. regularis, $C$. ehrenbergii, Micula spp., Rhagodiscus spp., W. barnesiae and Zeugrhabdotus spp. Variations in PCA1 and PCA2 match changes in bulk $\delta^{13} \mathrm{C}$ and $\delta^{18} \mathrm{O}$, respectively, and suggest changes in surface-water fertility and temperatures and associated stress. The variations in abundances of high-latitude taxa and the warm-water species Micula murus and in bulk $\delta^{18} \mathrm{O}$ delineate fast changes in sea-surface paleotemperatures. As in many other sites, an endMaastrichtian greenhouse warming is highlighted, followed by a short cooling and an additional warm pulse in the last $30 \mathrm{kyr}$ of the Maastrichtian which has rarely been documented so far. Orbital tuning of the delineated climatic events is proposed following the two different age models. Calcareous nannofossil assemblages highlight a decrease in surface-water nutriency, but their species richness remains high through the latest Maastrichtian, indicating, in Tunisia, a weak impact of Deccan volcanism on calcareous nannoplankton diversity before the mass extinction.
\end{abstract}

\section{Keywords}

Late Maastrichtian Cyclostratigraphy Calcareous nannofossils Paleoecology Stable isotopes 


\section{Introduction}

The Cretaceous-Paleogene boundary (K-PgB) mass extinction and associated paleoenvironmental perturbations have been extensively studied with increasingly high resolution (Abramovich et al. 2010; Bralower et al. 2010; Jiang et al. 2010; Schulte et al. 2010; Hull et al. 2011; Alegret et al. 2012). The last $500 \mathrm{kyr}$ of the Cretaceous is particularly critical as they are characterized by a global greenhouse warming event, most likely linked to Deccan $\mathrm{CO}_{2}$ degassing, followed by a short cooling interval immediately preceding the $\mathrm{K}-\mathrm{PgB}$ (Li and Keller 1998a, b; Abramovich and Keller 2002, 2003; Nordt et al. 2003; Wilf et al. 2003; Thibault and Gardin 2010). Several perturbations in foraminiferal and calcareous nannofossil assemblages have been recorded in association with this intense warming (Kucera and Malmgren 1998; Olsson et al. 2001; Abramovich and Keller 2002, 2003; Thibault and Gardin 2010). Central Tunisia (southwestern Tethys ocean) is of particular importance to address these issues because of its well-exposed $\mathrm{K}-\mathrm{PgB}$ sections that have a good continuity and are considered as the most biostratigraphically complete records, such as the El Kef global stratotype section and point (GSSP) (Molina et al. 2006, 2009). The Elles section, situated $75 \mathrm{~km}$ southeast of El Kef (Fig. 1), has also been intensively studied for calcareous nannofossils, foraminifers, stable isotopes, clay mineralogy, $\mathrm{Sr} / \mathrm{Ca}$ variations and the potential expression of orbital cyclicities (Gardin 2002; Adatte et al. 2002; Stüben et al. 2003). However, past changes in sea-surface-water temperatures have not been clearly demonstrated and paleoenvironmental changes preceding the $\mathrm{K}-\mathrm{Pg}$ mass extinction lack the precise timing that cyclostratigraphy can nowadays establish (Husson et al. 2014a). For instance, although orbital cycles have been retrieved from several proxies in the Elles section, these records have not been tuned into the time domain, and the timescale of events preceding the $\mathrm{K}-\mathrm{PgB}$ was mainly applied based on average sedimentation rates and biostratigraphy (Stüben et al. 2003). No bulk stable isotope record has yet been published for this section although it bears valuable information in addition to existing stable isotope data on separated benthic and planktic foraminifers (Stüben et al. 2003). Here, we use high-resolution magnetic susceptibility data to establish a precise orbital calendar of paleoenvironmental events for one of the most complete records of the latest Cretaceous and investigate bulk stable isotopes and calcareous nannofossil assemblages for a potential response to paleoclimatic changes preceding the mass extinction. 


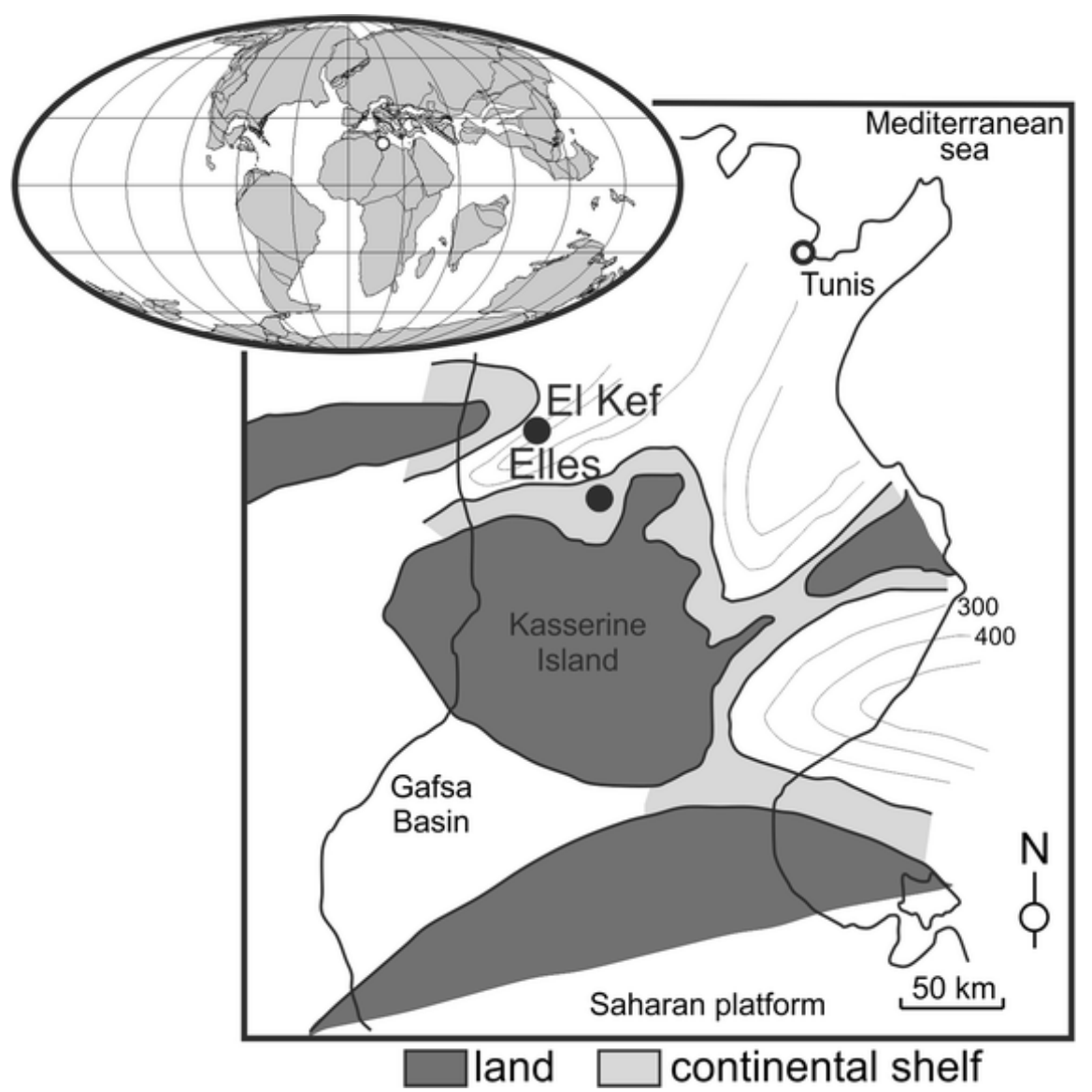

Fig. 1 : Palaeogeographic position of the Elles section. Modified after Burollet (1967)

\section{Materials and methods}

\section{Paleogeographical setting and lithology of the Elles section}

Outcrops of the Elles section, central Tunisia, span a continuous succession from the Campanian to the Eocene. During the Late Cretaceous, the Elles section was situated on the epicontinental shelf of the emerged Kasserine island (Burollet 1967, Fig. 1). Paleodepth has been estimated between 100 and $150 \mathrm{~m}$ using ostracod assemblages (Peypouquet et al. 1986). The sedimentology of this section was already described in detail in a number of studies (Said 1978; Zaghbib-Turki et al. 2000). Sediments of the studied section belong to the El Haria Formation and can be divided into five main units (Fig. 2): 


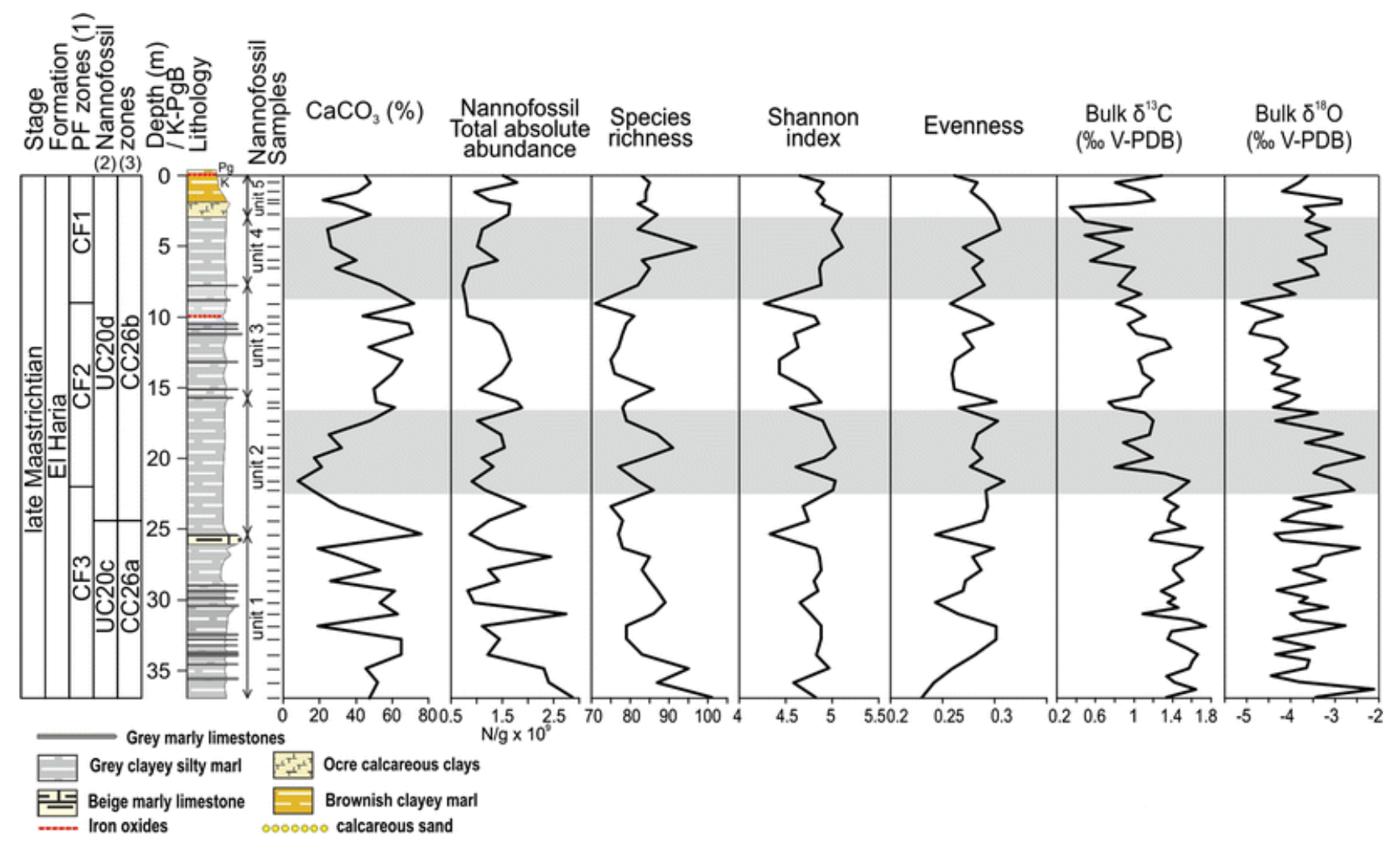

Fig. 2: Lithology, calcium carbonate content, total nannofossil abundance, nannofossil diversity indices and bulk oxygen and carbon isotopes of the studied Elles Sect. (1) Planktic foraminifer (PF) zones after Abramovich and Keller (2002). (2) Zonation of Burnett (1998). (3) Zonation of Perch-Nielsen (1985)

- Unit 1 ( -37 to $-25.5 \mathrm{~m}$ ): gray to dark gray silty marls alternating with 5 - to 15 -cm-thick dark gray marly limestones. The top of this unit is marked by a distinctive $70-\mathrm{cm}$-thick pale yellow marly limestone bed.

- Unit $2(-25.5$ to $-15.75 \mathrm{~m})$ : gray silty marls throughout.

- Unit 3 (-15.75 to $-7.7 \mathrm{~m})$ : gray to pale gray silty marls alternating with 10 - to 15 -cm-thick dark gray marly limestones. A distinctive reddish level of iron oxides is observed at $-10 \mathrm{~m}$. The top of this unit is marked by a millimetric layer of yellow carbonated sand on top of the upper marly limestone bed (Fig. 2).

- Unit $4(-7.7$ to $-2.9 \mathrm{~m})$ : gray silty marls throughout.

- Unit $5(-2.9$ to $0 \mathrm{~m})$ : marked at the base by a distinctive 1-m-thick level of ocre calcareous clays, followed by brownish clayey marls and topped by the reddish clay of the $\mathrm{K}-\mathrm{Pg}$ boundary, rich in gypsum and iron oxides. In the last $4 \mathrm{~cm}$ below the $\mathrm{K}-\mathrm{Pg}$ boundary, Adatte et al. (2002) noticed, within this unit, a foraminiferal packstone interpreted as a transgressive surface.

\section{Sampling resolution and analysis}

Three hundred and forty-nine samples were analyzed for magnetic mass susceptibility (MS) with an average sampling resolution of ca. $15 \mathrm{~cm}$ between -37 and $-32 \mathrm{~m}$ and ca. $10 \mathrm{~cm}$ from -32 m onward. Measurements were obtained with a Kappa bridge KLY-2, and the given results correspond to the average of three measurements standardized by the weight of the sample (in $10^{-8} \mathrm{~m}^{3} / \mathrm{kg}$ ). Magnetic susceptibility measures the capacity of a substance to acquire magnetization when submitted to an external magnetic field. It is commonly used for 
cyclostratigraphy in many marine sedimentary records because high-frequency MS variations are directly related to the relative terrigenous supply which is controlled by orbitally forced variations in insolation (Ellwood et al. 2000).

Oxygen- and carbon-isotopic composition of bulk carbonates were measured with a mass spectrometer Finnigan Delta $E$ on 82 samples (with an average resolution of $50 \mathrm{~cm}$ ) at the Laboratoire Biominéralisations et environnements sédimentaires (Université Pierre et Marie Curie, Paris 6, France). The extraction of $\mathrm{CO}_{2}$ was done by reaction with anhydrous orthophosphoric acid at $50{ }^{\circ} \mathrm{C}$. The analytical precision is estimated at $0.1 \%$ for oxygen and $0.05 \%$ for carbon.

For calcareous nannofossil analysis, 44 samples were processed as follows: Sediments were gently disaggregated in a mortar, and $50 \mathrm{mg}(\mathrm{M})$ of dried sediment was weighed and dispersed in $50 \mathrm{ml}(\mathrm{V})$ of distilled water. The suspension was ultrasonicated for $10 \mathrm{~s}$ and homogenized with a magnetic stirrer. One milliliter of this suspension was extracted with a finnpipette and homogeneously dropped on a coverslip. Particles are therefore evenly distributed on the coverslip. The coverslip was then mounted on a slide with adhesive. Quantitative counts and estimation of the species richness were performed at a magnification of $\times 1575$ ( $\times 63$ oil objective with a $\times 2.5$ additional lense). The total nannofossil abundance (number of specimens per gram of sediment, $X$ ) was calculated with the following parameters: $X=\left(N \times S_{\text {cl }} \times V\right) /(S$ for $\times$ FOV $\times M)$, where $N=$ total number of counted specimens, $S$ $\mathrm{cl}=$ surface area of the coverslip $\left(864 \mathrm{~mm}^{2}\right), S_{\text {fov }}=$ surface area of one field of view $\left(0.0172 \mathrm{~mm}^{2}\right)$, and FOV = total number of investigated fields of view.

In order to record accurately variations in relative abundances of rare to very rare species, the total number of counted specimens was at least 500 for each investigated sample. With this high number of specimens counted, a variation of only $1 \%$ of rare species represents an increase from 5 to 10 specimens observed per slide, which is statistically meaningful (Patterson and Fishbein 1989). The Shannon-Wiener diversity index was calculated. This index is much used in ecology because it comprises information on both diversity and evenness of the assemblage by taking into account the species richness and the associated relative abundance of each species. Changes in ecological assemblages composed of many species can actually be better described through the classic use of principal component analysis (PCA). This multivariate statistical method simplifies the interpretation of complex datasets with numerous variables by reducing the information contained in the data matrix to a limited number of factors (PCA factors) that express the highest variance in the total assemblage. Prior to the PCA analysis, species were regrouped by taxonomic affinity in order to reduce the number of variables. Placozygus spiralis was grouped along with Zeugrhabdotus species as Zeugrhabdotus spp., and all Prediscosphaera were grouped together, except $P$. stoveri which was considered separately because of its high percentage and distinctive changes in abundance. PCA was performed in R-mode on the centered reduced matrix (all abundances standardized by the mean and standard deviation). Calcium carbonate measurements were performed with a carbonate bomb on the same 44 samples processed for nannofossil investigations.

\section{Cyclostratigraphic methods}

The cyclostratigraphic analysis was performed on MS variations. Prior to the analysis, data were regularly interpolated at $5 \mathrm{~cm}$ and long-term trends were removed from the original signal using a robust loess-smoothing weighted average under Matlab ${ }^{\mathrm{TM}}$ over $27 \%$ of the total time series (190 out of a total of 738 data points of the interpolated time series, Figs. $\underline{3}$, 4). Spectral analyses were performed using the multitaper method (MTM, Thomson 1982) with a red noise simulation from Schulz and Mudelsee (2002) developed for Matlab ${ }^{\mathrm{TM}}$ by 
Husson et al. (2014b). The red noise simulation allows the estimation of confidence levels based on a Chi-square statistical test performed on the theoretical spectrum of the red noise. In addition, two running time-frequency spectral tools are used: the wavelet transform using the Matlab ${ }^{\mathrm{TM}}$ script of Grinsted et al. (2004) and the amplitude spectrogram method developed by Maurer et al. (2004), which corresponds to a succession of fast Fourier transform spectral analyses, performed at a constant step along the time series within a sliding window. For analysis in the depth domain, a window of $5 \mathrm{~m}$ and a step of $0.1 \mathrm{~m}$ were chosen. The resulting amplitude spectrogram thus covers part of the time series only, with $2.5 \mathrm{~m}$ (half of the chosen window) being cut away at each edge. In order to extract the potential cyclicities identified by the cyclostratigraphic analysis, we used Taner filters (Taner 2000) for high-precision extraction of specific astronomical frequency targets. Orbital tuning based on the identification of Milankovitch frequencies was used to provide a relative timescale and to propose ages of nannofossil bio-horizons and previously recorded planktic foraminifer bio-horizons (Abramovich and Keller 2002). This tuning is only based on the identification of Milankovitch frequencies; calibration to astronomical solutions was not possible here due to the short length of the record. After tuning the time series, the same analyses were performed again in the time domain. The age of relevant biostratigraphic horizons is calculated for two options using an age of $66 \mathrm{Ma}$ for the K-PgB (Kuiper et al. 2008; Husson et al. 2011; Renne et al. 2013).

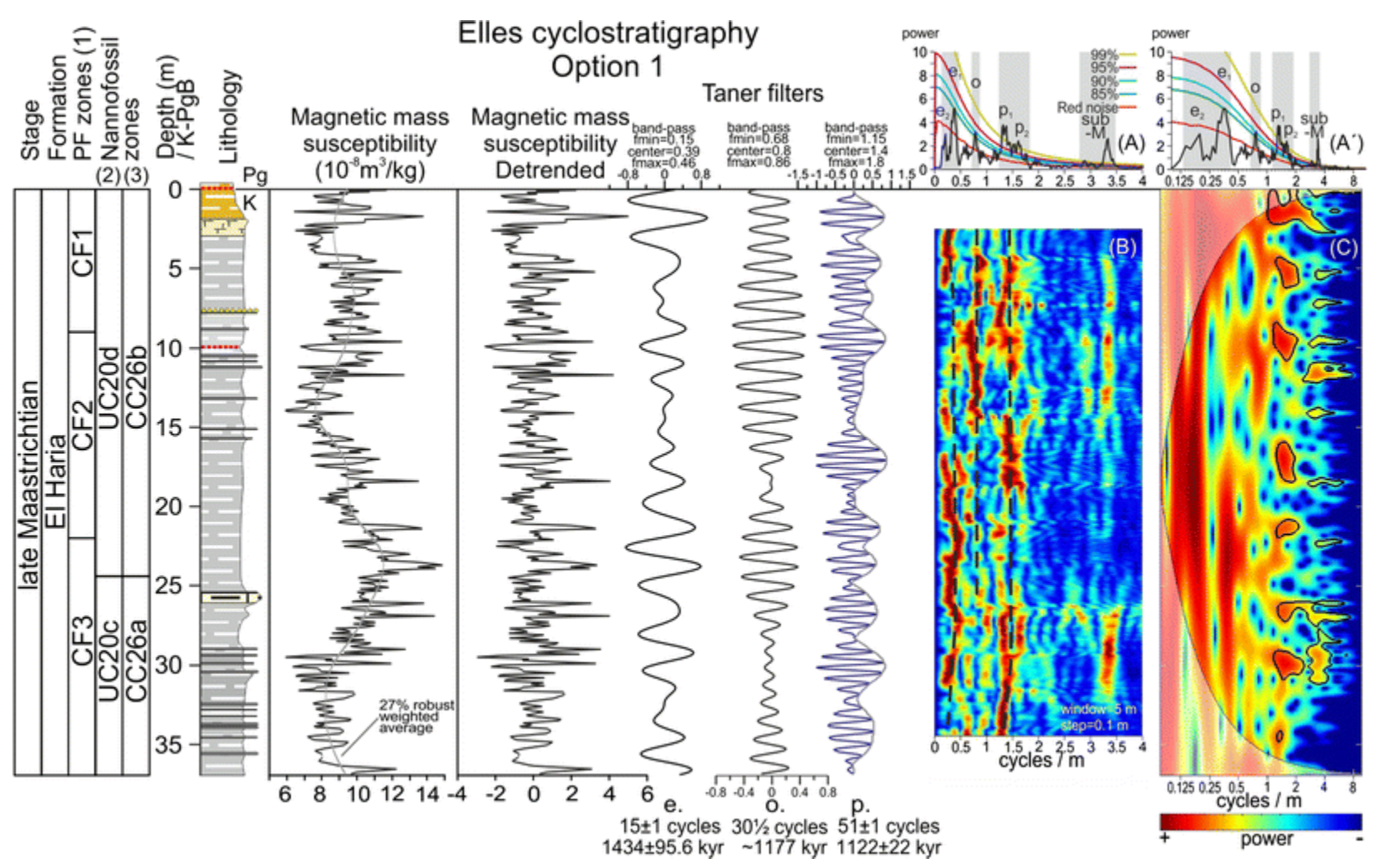

Fig. 3 :Cyclostratigraphic analysis of the Elles section (option 1). a 4m MTM with red noise model and $X^{2}$ significance levels. $a^{\prime}$ Same with a log2 scale on the x-axis. $\boldsymbol{b}$ Amplitude spectrogram of the time series. $c$ Wavelet spectrum of the time series. sub-M subMilankovitch cyclicities 


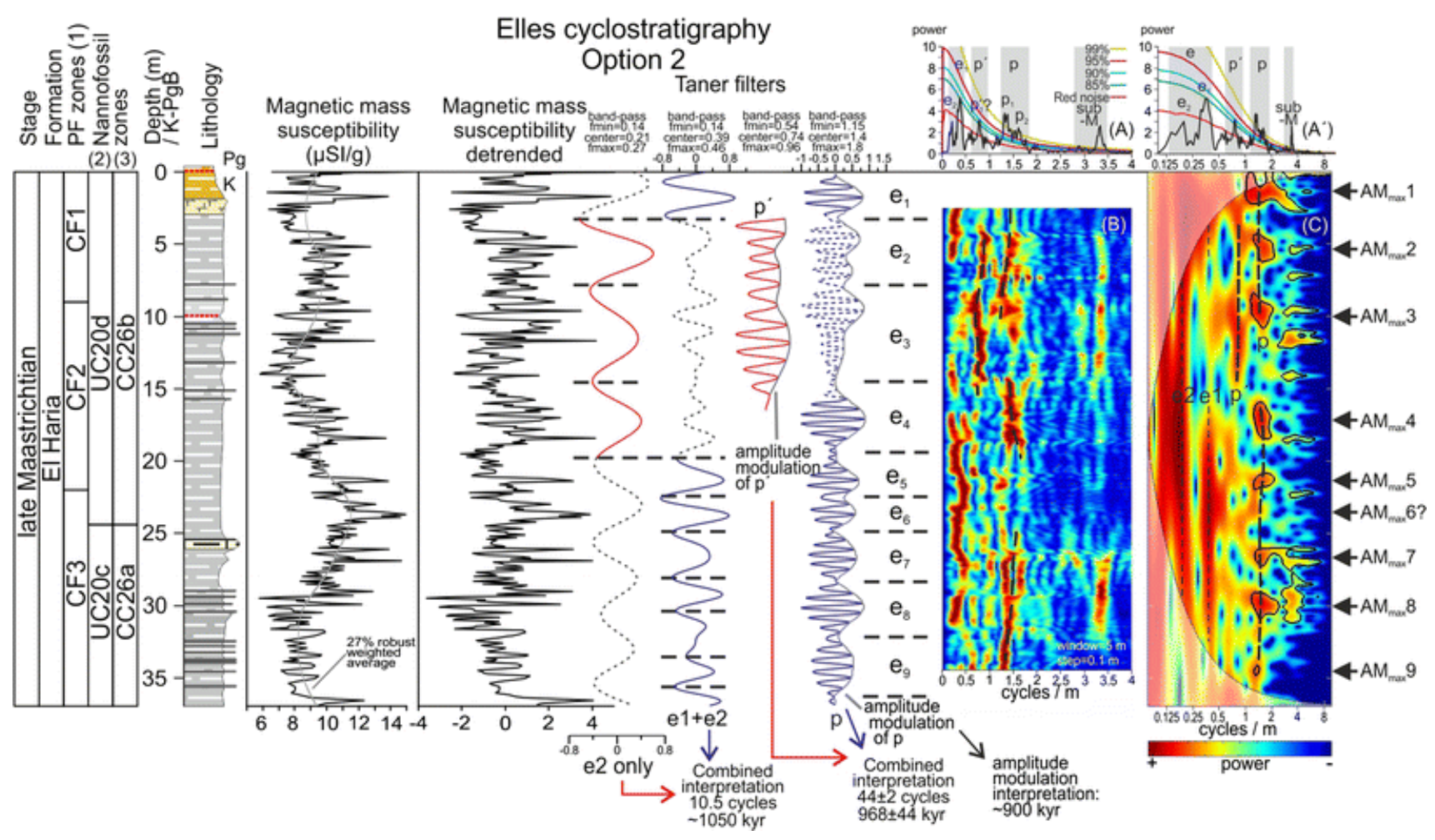

Fig. 4 :Cyclostratigraphic analysis of the Elles section (option 2). a 4m MTM with red noise model and $x^{2}$ significance levels. $a^{\prime}$ Same with a log2 scale on the $\mathrm{x}$-axis. $\boldsymbol{b}$ Amplitude spectrogram of the time series. c Wavelet spectrum of the time series. sub-M subMilankovitch cyclicities

\section{Results}

\section{Cyclostratigraphy in the depth domain}

Results of the MTM spectral analysis on the detrended MS variations highlight two highly significant frequencies, respectively, centered around 1.35 and $1.6 \mathrm{cycles} / \mathrm{m}$ (Fig. 5). Two other peaks reach close to the $90 \%$ significance level at 0.78 and 0.37 cycles $/ \mathrm{m}$, whereas a less significant peak can be observed at around 0.22 cycles $/ \mathrm{m}$ (Fig. 5). An additional highly significant frequency is expressed at 3.4 cycles/m (Figs. $\underline{3 a}, \underline{4 a}$ ). 


\begin{tabular}{llrrrlllllll} 
(A) & & e2 & e1 & e3 & o2 & o1 & o3 & p1 & p2 & p3 \\
La2004 & (kyr) & 128 & 95.6 & 76 & 50.6 & 38.2 & 28.8 & 22.9 & 21.8 & 18.5 & 16 \\
\hline e2 & 128 & 1 & 0.75 & 0.59 & 0.40 & 0.30 & 0.23 & 0.18 & 0.17 & 0.14 & 0.13 \\
e1 & 95.6 & 1.34 & 1 & 0.79 & 0.53 & 0.40 & 0.30 & 0.24 & 0.23 & 0.19 & 0.17 \\
e3 & 76 & 1.68 & 1.26 & 1 & 0.67 & 0.50 & 0.38 & 0.30 & 0.29 & 0.24 & 0.21 \\
o2 & 50.6 & 2.53 & 1.89 & 1.50 & 1 & 0.75 & 0.57 & 0.45 & 0.43 & 0.37 & 0.32 \\
o1 & 38.2 & 3.35 & 2.50 & 1.99 & 1.32 & 1 & 0.75 & 0.60 & 0.57 & 0.48 & 0.42 \\
o3 & 28.8 & 4.44 & 3.32 & 2.64 & 1.76 & 1.33 & 1 & 0.80 & 0.76 & 0.64 & 0.56 \\
p1 & 22.9 & 5.59 & 4.17 & 3.32 & 2.21 & 1.67 & 1.26 & 1 & 0.95 & 0.81 & 0.70 \\
& 21.8 & 5.87 & 4.39 & 3.49 & 2.32 & 1.75 & 1.32 & 1.05 & 1 & 0.85 & 0.73 \\
p2 & 18.5 & 6.92 & 5.17 & 4.11 & 2.74 & 2.06 & 1.56 & 1.24 & 1.18 & 1 & 0.86 \\
p3 & 16 & 8.00 & 5.98 & 4.75 & 3.16 & 2.39 & 1.80 & 1.43 & 1.36 & 1.16 & 1 \\
\hline
\end{tabular}

\begin{tabular}{|c|c|c|c|c|c|c|c|c|c|c|c|}
\hline (B) & & e2 & e1/e3? & 02 & $02 ?$ & $01 / p^{\prime}$ & o3 & 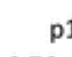 & & p2 & p3 \\
\hline Elles & $(\mathrm{m})$ & 4.55 & 2.60 & 1.77 & 1.62 & 1.26 & 0.87 & 0.76 & 0.72 & 0.62 & 0.57 \\
\hline e2 & 4.55 & 1 & 0.57 & 0.39 & 0.36 & 0.28 & 0.19 & 0.17 & 0.16 & 0.14 & 0.13 \\
\hline e1/e3? & 2.6 & 1.75 & 1 & 0.68 & 0.62 & 0.48 & 0.33 & 0.29 & 0.28 & 0.24 & 0.22 \\
\hline 02 & 1.77 & 2.57 & 1.47 & 1 & 0.92 & 0.71 & 0.49 & 0.43 & 0.41 & 0.35 & 0.32 \\
\hline $02 ?$ & 1.62 & 2.81 & 1.60 & 1.09 & 1 & 0.78 & 0.54 & 0.47 & 0.44 & 0.38 & 0.35 \\
\hline $01 / p^{\prime}$ & 1.26 & 3.61 & 2.06 & 1.40 & 1.29 & 1 & 0.69 & 0.60 & 0.57 & 0.49 & 0.45 \\
\hline 03 & 0.87 & 5.23 & 2.99 & 2.03 & 1.86 & 1.45 & 1 & 0.87 & 0.83 & 0.71 & 0.66 \\
\hline n & 0.76 & 5.99 & 3.42 & 2.33 & 2.13 & 1.66 & 1.14 & 1 & 0.95 & 0.82 & 0.75 \\
\hline$p_{1}$ & 0.72 & 6.32 & 3.61 & 2.46 & 2.25 & 1.75 & 1.21 & 1.06 & 1 & 0.86 & 0.79 \\
\hline p2 & 0.62 & 7.34 & 4.19 & 2.85 & 2.61 & 2.03 & 1.40 & 1.23 & 1.16 & 1 & 0.92 \\
\hline p3 & 0.57 & 7.98 & 4.56 & 3.11 & 2.84 & 2.21 & 1.53 & 1.33 & 1.26 & 1.09 & \\
\hline
\end{tabular}

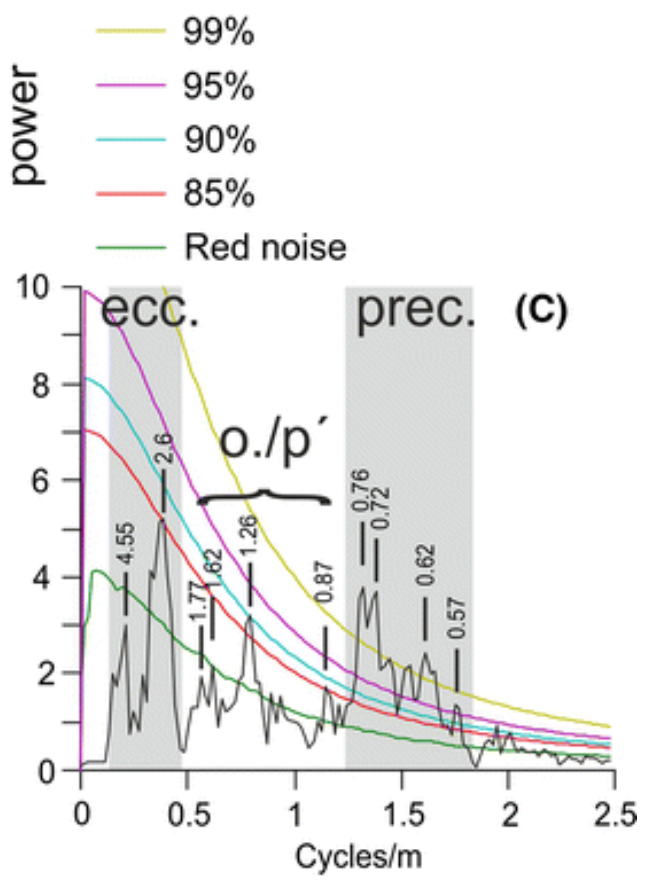

Fig. 5 : Comparison of frequency ratios between Elles and the La2004 astronomical solution. a Ratios between the main frequency peaks (in kyr) expressed in the La2004 solution for the 66-70 Ma interval. e1, e2, e3, o1, o2, o3 and p1, p2, p3 refer to the peaks of the eccentricity, obliquity and precession by order of importance. $\boldsymbol{b}$ Ratios between the main frequency peaks (in $m$ ) expressed in the power spectrum of the Elles section. c 4T MTM power spectrum for the Elles section MS measurements

All those periodicities are significantly highlighted with high powers in the amplitude spectrogram (Figs. $3 b, 4 b$ ). Within the most significant frequency band centered around 1.5 cycles/m and highlighted in gray (peaks at 1.35 and 1.6, Fig. $3 a$ ), regular variations in amplitude are suggested by bifurcations in the amplitude spectrogram (Fig. $\underline{3 b}$ ) and variations in the power of the frequency in the wavelet transform (Fig. 3c). These observations reflect amplitude modulations in this frequency band which is generally characteristic of eccentricitymodulated precession forcing affecting p1 and p2 (Hinnov 2000; Husson et al. 2014b). Comparing frequency ratios between the peaks expressed in the power spectrum of Elles and the main significant periodicities of the eccentricity, obliquity and precession expressed in the La2004 astronomical solution (Laskar et al. 2004) for the 66-70 Ma interval confirm the preceding interpretation and permit the identification of orbital periods in the studied section (Fig. 5). A first interpretation (option 1) points to few variations in sedimentation rate and a simple extraction of the three main well-expressed frequency bands of the eccentricity, obliquity and precession through the use of a band-pass Taner filter (highlighted in gray in Fig. 3). The resulted filter of the eccentricity band is difficult to interpret for cycle counting, presenting several doubtful cycles with very low amplitudes at ca. 7,15 and $32.5 \mathrm{~m}$ (Fig. 3 ). Cycle counts along this filter may point to $15 \pm 1$ cycles for the entire section. Cycle counting of the obliquity and precession band filters points, respectively, to $301 / 2$ and $51 \pm 1$ cycles (Fig. 3). While considering the average duration of the main peaks of Milankovitch periodicities of the La2004 solution for the 66-70 Ma interval (Laskar et al. 2004; Fig. 6), this counting points to a duration of $1434 \pm 95.6 \mathrm{kyr}$ for the eccentricity filter, ca. $1177 \mathrm{kyr}$ for the obliquity filter and $1122 \pm 22 \mathrm{kyr}$ for the precession filter (Fig. 3 ). These results point to a 
relatively good agreement between the obliquity and precession counting and an offset of more than $200 \mathrm{kyr}$ with respect to the estimation from the eccentricity filter. Three 405 eccentricity cycles would be expected in the long-term trends of the MS signal in line with the previous interpretation. This periodicity is expressed with a high-power peak at ca. 0.07 cycles $/ \mathrm{m}$ (period of ca. $14 \mathrm{~m}$ ) on a spectrum performed on non-detrended data. However, periodicities represented by less than 3 cycles in an entire timeseries are very difficult to highlight with precision in a power spectrum (Weedon 2003). No clear filtering extraction of this periodicity was possible to perform here, but the robust weighted average of the MS signal points to the expression of two long-term cycles only (Fig. 3 ). The significant frequency centered at $3.3 \mathrm{cycles} / \mathrm{m}$ bears a periodicity which is two to three times higher than the sampling resolution. In line with our interpretation, this frequency may correspond to the expression of sub-Milankovitch cycles.

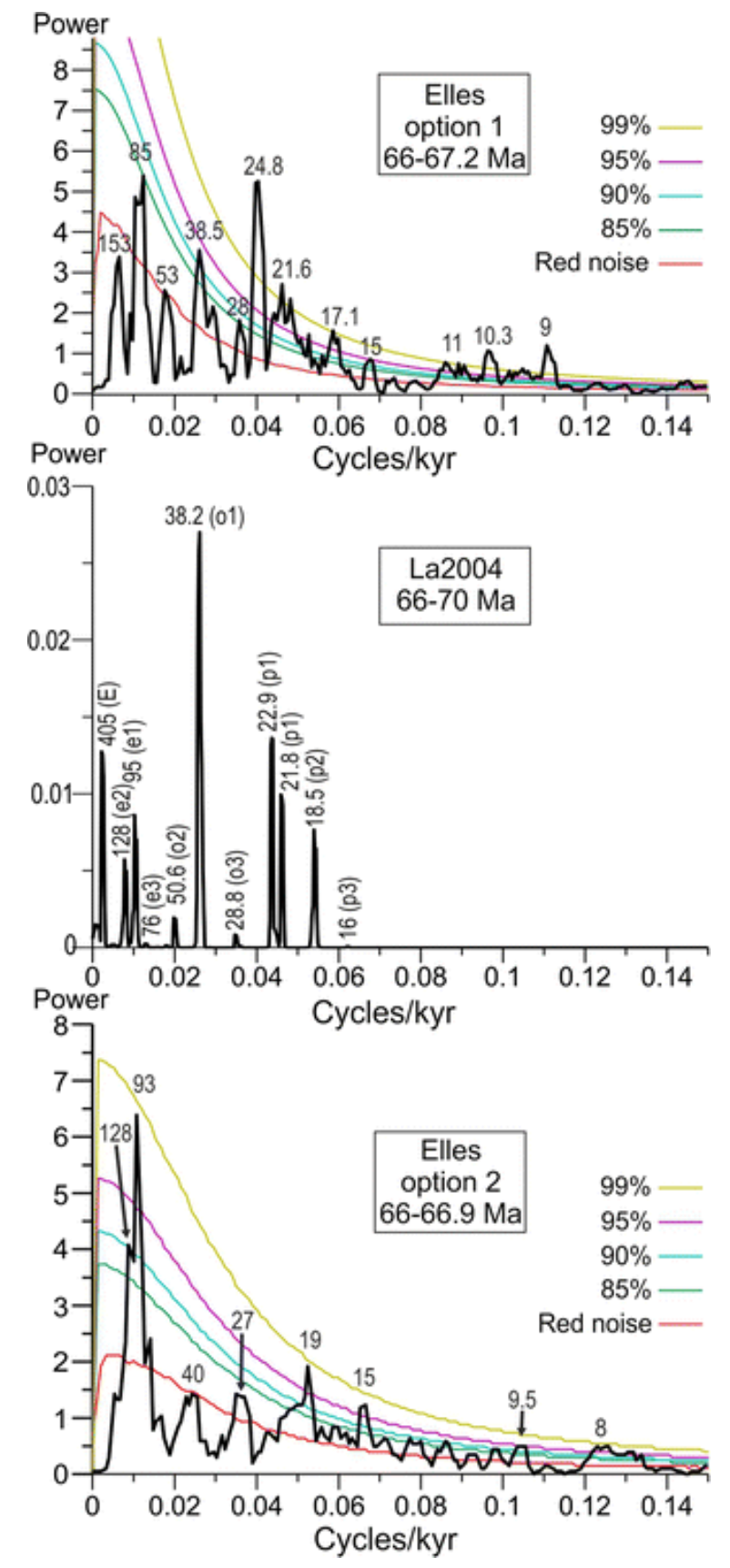

Fig. 6 : Comparison of 4T MTM power spectra performed in the time domain for options 1 and 2 on the magnetic susceptibility of the Elles section with a $4 \pi$ MTM power spectrum of the La2004 astronomical solution for the 66 to $70 \mathrm{Ma}$ interval 
Several features of the cyclostratigraphic analysis suggest a different and more complex interpretation of the cyclicity in the Elles record which implies important changes in the sedimentation rate (option 2, Fig. 4). This interpretation relies on the unexpectedly high expression of the obliquity in this low-latitude site and on the expression of amplitude modulations and variations in the power of the different frequency bands in the wavelet and in the amplitude spectrogram (Fig. 4). Within the most significant frequency band centered around 1.5 cycles/m ( 1 1 + p2), regular variations in amplitude are suggested by bifurcations in the amplitude spectrogram (Fig. $\underline{4 b}$ ) and by variations in the power of this frequency in the wavelet transform (Fig. 4c). These variations in the wavelet occur with a wavelength ranging between 2 and $4 \mathrm{~m}$ which would correspond to the frequency range of the eccentricity band $(\mathrm{e} 1+\mathrm{e} 2)$ (Fig. 4). These variations reflect amplitude modulations of the $1.5 \mathrm{cycles} / \mathrm{m}$ frequency with an average cycle ratio close to 1:5 which is typical of short-eccentricitymodulated precession forcing (Hinnov 2000). A significant change occurs between -5 and $-15 \mathrm{~m}$ in the amplitude and wavelet spectrogram with a high-power expression within the frequency band labelled p', previously interpreted as the obliquity in option 1 and centered around 0.79 cycles/m (Fig. 4). Within this interval, the power of $p$ is also significantly lowered and perturbated, and the power of the overall eccentricity band (e1+e2 on Fig. $4 a$ ) is absent in the amplitude spectrogram (Fig. 4b). In option 2, it is assumed that the expression of p' between -5 and $-15 \mathrm{~m}$ actually corresponds to a sudden shift in the precession band $p$ toward lower frequencies, due a sudden increase in sedimentation rate. In this interval, the disappearance of the eccentricity frequency band from the amplitude spectrogram could then be explained by a shift to a lower frequency corresponding to a period longer than the 5-m window of the analysis (Fig. 4b). In the wavelet spectrogram (Fig. 4c), high power of e1 is also expressed centered at 0.4 cycles/m from 0 to $-5 \mathrm{~m}$ and from -15 to the base of the section, but this component is poorly significant in the MTM (Fig. $\underline{4}$ a) and shows a very low power on the amplitude spectrogram in the interval between -5 and $-15 \mathrm{~m}$ (Fig. $4 \mathrm{~b}$ ). These results would suggest that an important increase in the sedimentation rate occurred within the -5 to $-15 \mathrm{~m}$ interval, shifting the significant frequencies to a different range of values. This interpretation can explain the discrepant interpretations in the counting of cycles obtained from the Taner filter of the eccentricity and precession bands in option 1 (Fig. 3). Filtering of the $p$ frequency band results in a signal that presents clear amplitude modulations. These amplitude variations are extracted using a Hilbert transform which highlights the envelope of the filter (Fig. 4). This envelope points to the expression of 9-10 significant cycles only. However, if our recognition of the eccentricity-modulated precession is correct, it is expected to find about 4-6 precession cycles within each of the envelope cycles. This is not the case between -3 and $-8 \mathrm{~m}$ where only 6 cycles of $\mathrm{p}$ can be counted within the 2 envelope cycles (Fig. 4). Therefore, it is likely that the two cycles of the envelope actually correspond to only one eccentricity cycle. Between -8 and $-15 \mathrm{~m}$, only one significant cycle is present in the Hilbert envelope of the precession, but this corresponds to about nine cycles of $p$. This interval corresponds to the perturbated interval described above in the amplitude and wavelet spectrograms, where we suppose a shift in frequencies from $p$ to $p^{\prime}$. Therefore, in this interval, the extraction of the precession may actually be better resolved by the $p^{\prime}$ filter, while extraction of the eccentricity would be better resolved through extraction of the e2 frequency peak only (Fig. 4). Such an interpretation would respect the average ratio of $1: 5$ cycles between the precession and eccentricity. Taking all these results into account points to the identification of ca. 10.5 eccentricity cycles while combining the filters of e1 + e2 and e2 only (Fig. 3bis). A total duration of $968 \mathrm{kyr}$ can be calculated from the combination of the $p$ and $p^{\prime}$ filters (Fig. 3bis) and nine amplitude modulation cycles named AM1 to AM9 are identified with their maxima highlighted in Fig. 3 bis. Option 2 thus points to less discrepancy between the 
extraction of eccentricity and precession cycles than in option 1. Option 2 would also be relatively concordant with the two long cycles of the robust weighted average which likely represent the expression of the 405 kyr eccentricity (Fig. 4 ).

\section{Cyclostratigraphy in the time domain}

Cyclostratigraphic analysis in the time domain is fundamental because if the tuning is accurate, then Milankovitch frequencies should be better defined, potentially with higher power in the MTM of the new timeseries. Due to the chaotic behavior of the solar system, the $405 \mathrm{kyr}$ component of the eccentricity is the only orbital parameter stable over the MesoCenozoic (Laskar et al. 2004). In the absence of well-expressed 405 eccentricity cycles in the Elles sedimentary record, the most suitable Milankovitch component for building a cyclostratigraphic time frame should be the obliquity because it is a relatively stable component with a well-defined peak distributed over a very narrow frequency band in the astronomical solution (Fig. $\underline{7}$ a).

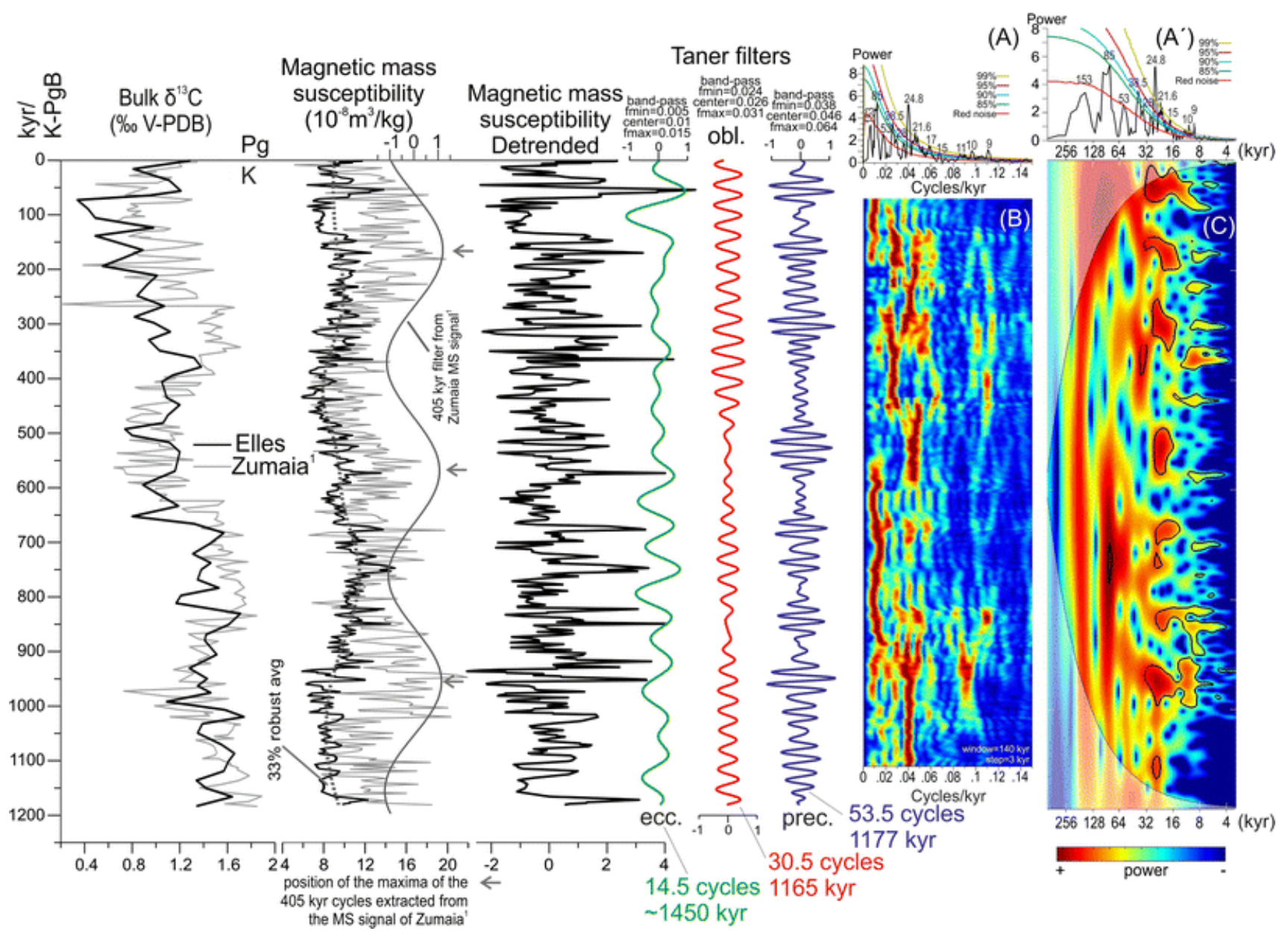

Fig. 7 : Cyclostratigraphy of the Elles tuned time series in option 1 and comparison with the tuned time series of Zumaia for the bulk $\delta^{13} \mathrm{C}$ and magnetic susceptibility (MS). (1) Batenburg et al. (2012). a 4T MTM with red noise model and $X^{2}$ significance levels. a' Same with a log2 Scale on the x-axis. $\boldsymbol{b}$ Amplitude spectrogram of the time-series. $\boldsymbol{c}$ Wavelet spectrum of the time-series

If option 1 is correct, then orbital tuning should be based on the well-expressed obliquity. The tuning into the time domain for option 1 is thus based on the identification of the 30 obliquity 
cycles, taking an average duration of $38.2 \mathrm{kyr}$, corresponding to the expression of this frequency in the La2004 solution (Fig. 6 ). After the tuning, detrending was performed using a $33 \%$ weighted average. The MTM of the new time series highlights peaks above the $95 \%$ confidence level at 24.8, 21.6, 17.1, 10.3 and $9 \mathrm{kyr}$ (Fig. 7a). The MTM of the tuned time series in option 1 shows an improved expression of the precession and a striking similarity in the period of the obliquity with La2004 (Fig. $\underline{6}$ ). However, peaks of the eccentricity band remain poorly significant with periods at 153 and $85 \mathrm{kyr}$ which are poorly concordant with the La2004 solution (Fig. 6). While performing a new cyclostratigraphic analysis of the tuned time series based on option 1, the discrepancy in cycle counting remains important between the eccentricity filter and the precession and obliquity filters (Fig. $\underline{7}$ ). Also, the amplitude spectrogram shows the same perturbations as observed in the depth domain (Fig. $7 \mathrm{~b}$ ).

For option 2, tuning into the time domain was performed based on the identification of the nine amplitude modulation cycles e1 to e9 as highlighted in Fig. 8. The power spectrum of the obtained time series highlights a somewhat reduced power for the expression of the precession, though still significant (Fig. 6 ). However, this option results in a highly significant and much better expression of the eccentricity with peaks corresponding to periods of 128 and $93 \mathrm{kyr}$ which are concordant with La2004 (Fig. 6). A peak in the obliquity band is also present at $40 \mathrm{kyr}$ but with a low power as expected from a low-latitude site. Also, cyclostratigraphic analysis in the time domain for option 2 shows an amplitude spectrogram and a wavelet with slightly less perturbations, and the power of the eccentricity band remains significant throughout the entire time series within the same frequency band (Fig. $\underline{8} b, \mathrm{c}$ ). Finally, Taner filtering of the precession, obliquity and eccentricity bands in the time domain results in filters that provide similar durations after cycle counting (Fig. $\underline{8}$ ).

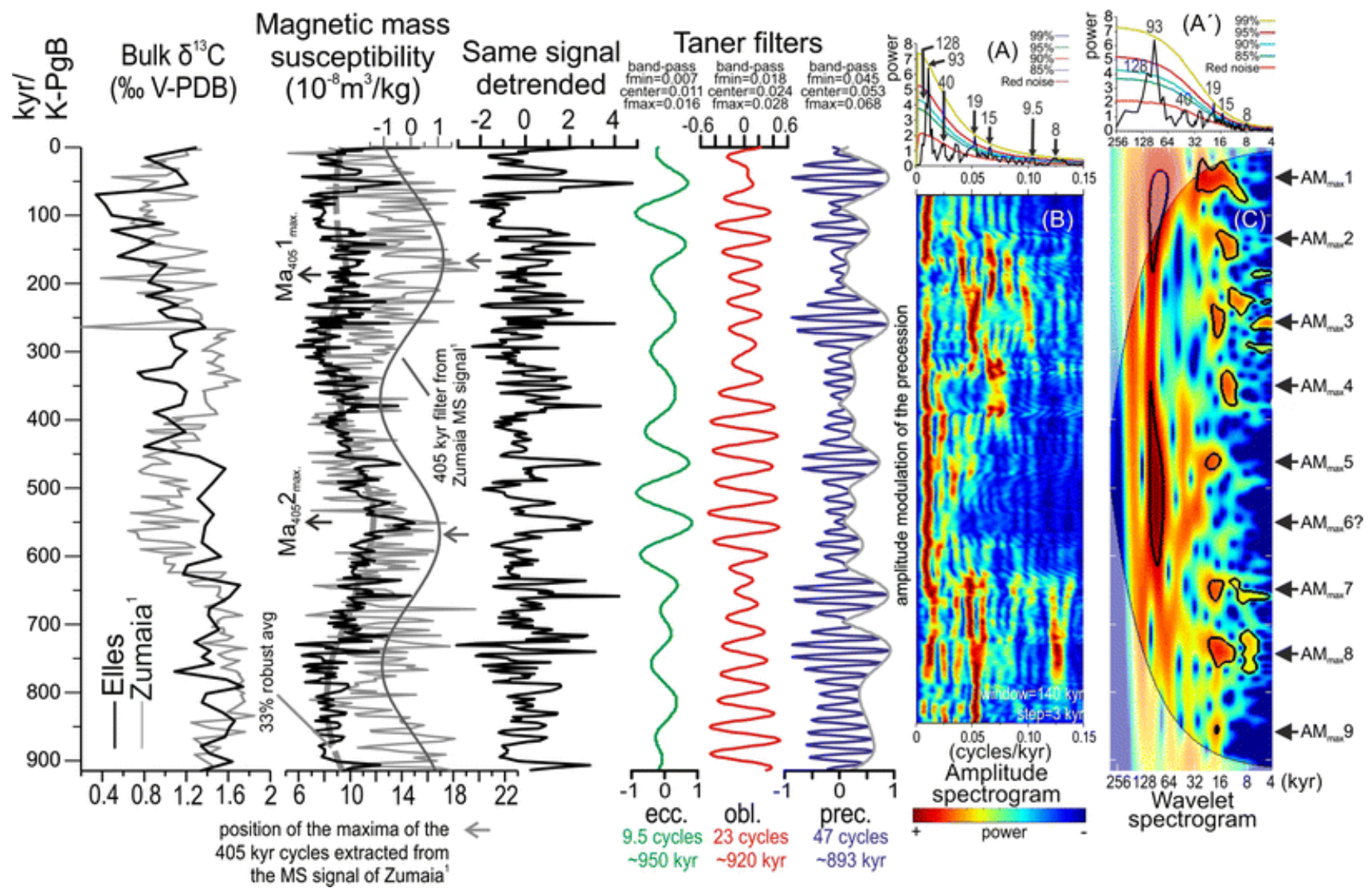

Fig. 8 : Cyclostratigraphy of the Elles tuned time series in option 2 and comparison with the tuned time series of Zumaia for the bulk $\delta^{13} \mathrm{C}$ and magnetic susceptibility (MS). (1) Batenburg 
et al. (2012). a 4T MTM with red noise model and $X^{2}$ significance levels. a' Same with a log2 scale on the x-axis. $\boldsymbol{b}$ Amplitude spectrogram of the time series. $\boldsymbol{c}$ Wavelet spectrum of the time series

\section{Calcium carbonate and stable isotopes}

Weight $\% \mathrm{CaCO}_{3}$ varies between 8 and $77 \%$ in the investigated samples and reproduces well the five different lithological units described above (Fig. 2). Low values characterize the two homogeneous marly intervals (highlighted in gray in Fig. 2). Higher values and more variability in carbonate content reflect marl-marly limestone alternations in the intervals between -37 and $-25.5 \mathrm{~m}$ and between -15.75 and $-7.7 \mathrm{~m}$. The interval between -2.9 and $0 \mathrm{~m}$ also shows slightly higher values than the gray marly interval below.

A cross-plot of carbon and oxygen isotopes is commonly used to test a possible diagenetic overprint which results in a positive correlation between the two ratios (Jenkyns et al. 1995; Mitchell et al. 1997). No significant trend is observed on the cross-plot (Fig. 9). Bulk $\delta^{18} \mathrm{O}$ values vary between -5.1 and $-2.1 \%$. The observed variations also match the observed lithological changes and weight $\% \mathrm{CaCO}_{3}$ with somewhat higher values characterizing the homogeneous marly intervals highlighted in gray (Fig. 2). The first interval of alternating marlmarly limestones $(-37$ to $-25.5 \mathrm{~m}$ ) is characterized by a high variability around of mean of $-3.5 \%$. In the homogeneous marly interval above, values oscillate around a mean of $-3.1 \%$. The second interval of alternating marl-marly limestones $(-15.75$ to $-7.7 \mathrm{~m})$ is characterized by a negative excursion with values oscillating around a mean of $-4.3 \%$ and minimal values reaching $-5.1 \%$ between -9 and $-11 \mathrm{~m}$. The second interval of homogeneous gray marls is characterized by a positive excursion with values reaching a maximum of $-3.1 \%$. A return to more negative values is observed in the three last samples of the studied interval (Fig. 2). Bulk $\delta^{13} \mathrm{C}$ values vary between 0.34 and $1.74 \%$. A progressive decrease is observed nearly throughout the section with values reaching the minimum of $0.34 \%$ at $-2.2 \mathrm{~m}$ within the ocre calcareous clays. From the base of the section to $-16.5 \mathrm{~m}$, the decrease in bulk $\delta^{13} \mathrm{C}$ appears to be stepwise (Fig. 2). Values sharply increase and reach ca. $1.2 \%$ in the last $2 \mathrm{~m}$ before the $\mathrm{K}-\mathrm{PgB}$.

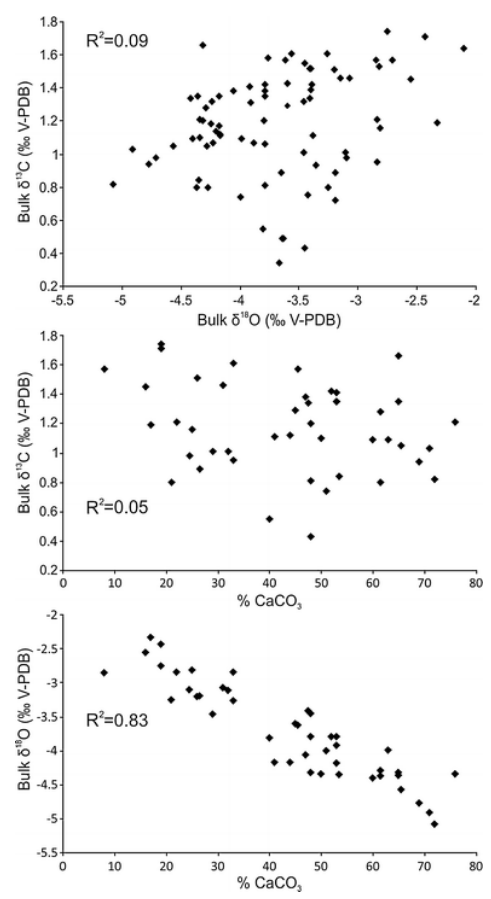

Fig. 9 : $\mathrm{X}-\mathrm{Y}$ plot of bulk $\delta^{13} \mathrm{C}$ versus bulk $\delta^{18} \mathrm{O}, \% \mathrm{CaCO}_{3}$ vs bulk $\delta^{13} \mathrm{C}$ and $\% \mathrm{CaCO}_{3}$ versus bulk $\delta^{18} \mathrm{O}$ 


\section{Calcareous nannofossils}

Similar to the results previously obtained by Gardin (2002), all the investigated samples of the Elles section yielded an abundant, highly diverse and well-preserved late Maastrichtian assemblage. The first occurrence of Micula prinsii which defines the base of the CC26b subzone of Perch-Nielsen (1985) and the UC20d $\mathrm{d}^{\mathrm{TP}}$ subzone of Burnett (1998) was found at $-24.4 \mathrm{~m}$, very close to the level identified in Gardin (2002). The total nannofossil abundance shows a high variability and the highest recorded values of $2.7 \times 10^{9} \mathrm{specimens} / \mathrm{g}$ in the first interval of marl-marly limestone alternations (Fig. 2). The species richness is extremely high as compared to other published records of late Maastrichtian nannofossil assemblages, with a minimum of 71 species at $-9 \mathrm{~m}$ and a maximum of 101 species at the base of the studied interval. The two homogeneous marly intervals are generally characterized by lower values in total nannofossil abundance and somewhat higher species richness. The Shannon index of the nannofossil assemblage is slightly higher in the two marly intervals and exhibit slightly lower values in the second interval of marl-marly limestone alternations and in the last $2.9 \mathrm{~m}$ below the K-PgB (Fig. 2).

Four taxa dominate the nannofossil assemblage (Fig. 10): Micula spp. (mainly M. decussata), Watznaueria barnesiae, Prediscosphaera cretacea and Discorhabdus rotatorius. Biscutum spp. have very low abundances, below $1 \%$. Dominance of solution-resistant taxa Micula and W. barnesiae in Late Cretaceous assemblages has generally been interpreted as a potential diagenetic overprint in abundance counts (Hill 1975; Thierstein 1980). A negative correlation between Micula and the total nannofossil abundance and/or between Micula and the species richness becomes significant in published successions with various preservations because as preservation worsens, much of the assemblage disappears while the abundance of solutionresistant species (Micula and W. barnesiae) increases (Roth and Krumbach 1986; Fisher and Hay 1999). Such a diagenetic overprint does not appear to have had an important influence on nannofossil assemblages of the Elles section. Because of its small size, $D$. rotatorius is one among the most sensitive species to dissolution and its abundance remains quite high throughout the Elles succession. No change in preservation has been noted in all investigated samples, and there is no significant correlation between Micula and the species richness $\left(r^{2}\right.$ Pearson correlation coefficient of 0.22 as compared to a $95 \%$ significance level at 0.26 for 42 degrees of liberty on a one-tailed test). No significant correlation is noted between Micula and the total nannofossil abundance $\left(r^{2}\right.$ Pearson correlation coefficient of 0.21). One studied sample at $-9 \mathrm{~m}$ shows a low nannofossil abundance, the lowest value in species richness and a peak in the relative abundance of Micula and W. barnesiae. Therefore, this sole sample may potentially be biased by a slight diagenetic overprint, and this is consistent with a minimal value in Bulk $\delta^{18} \mathrm{O}$ (Figs. 10, 11). Consequently, the changes observed in the relative abundance of nannofossil species can be interpreted in terms of paleoecological changes. 


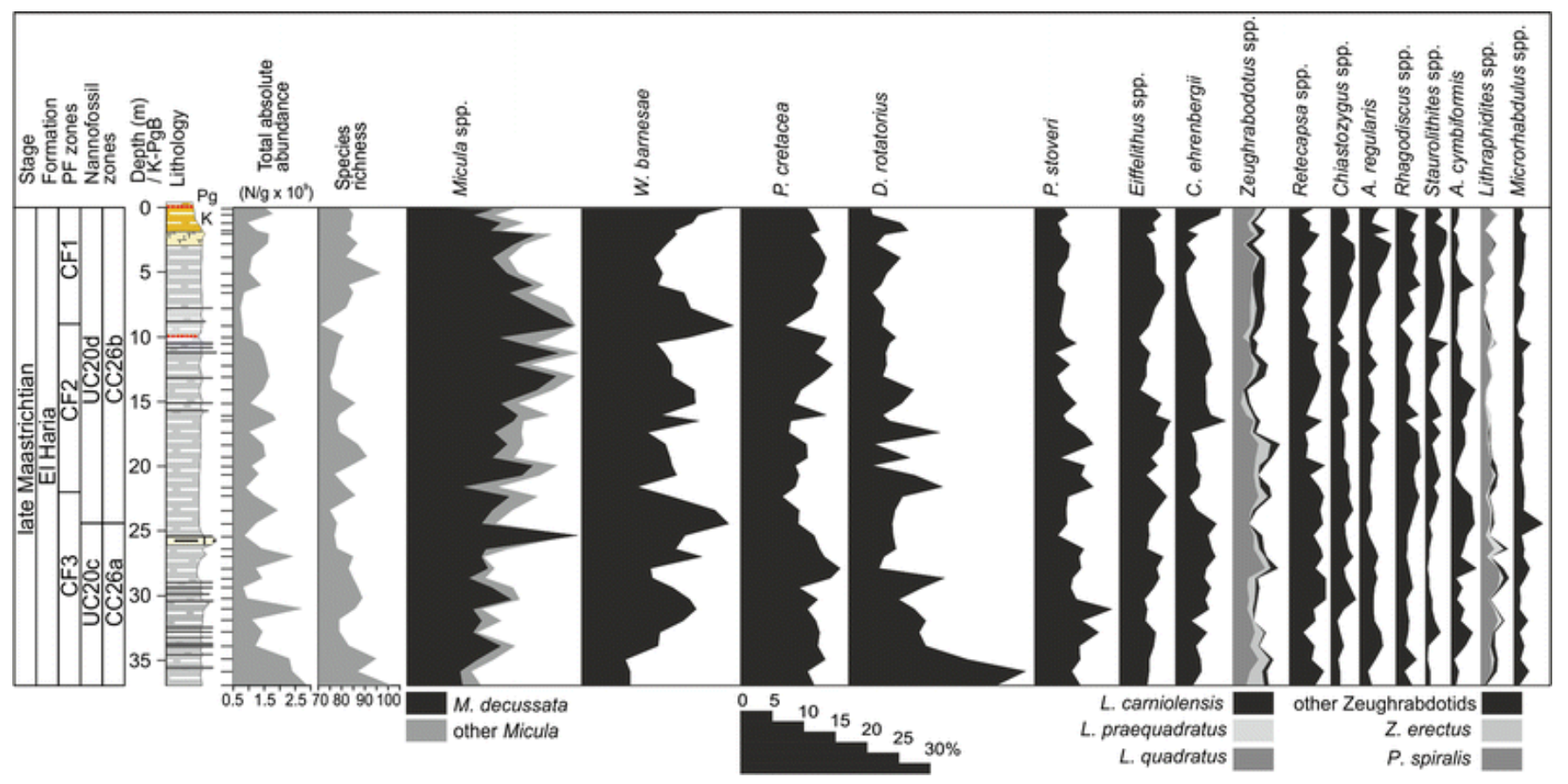

Fig. 10 : Composition of the nannofossil assemblage in the Elles section

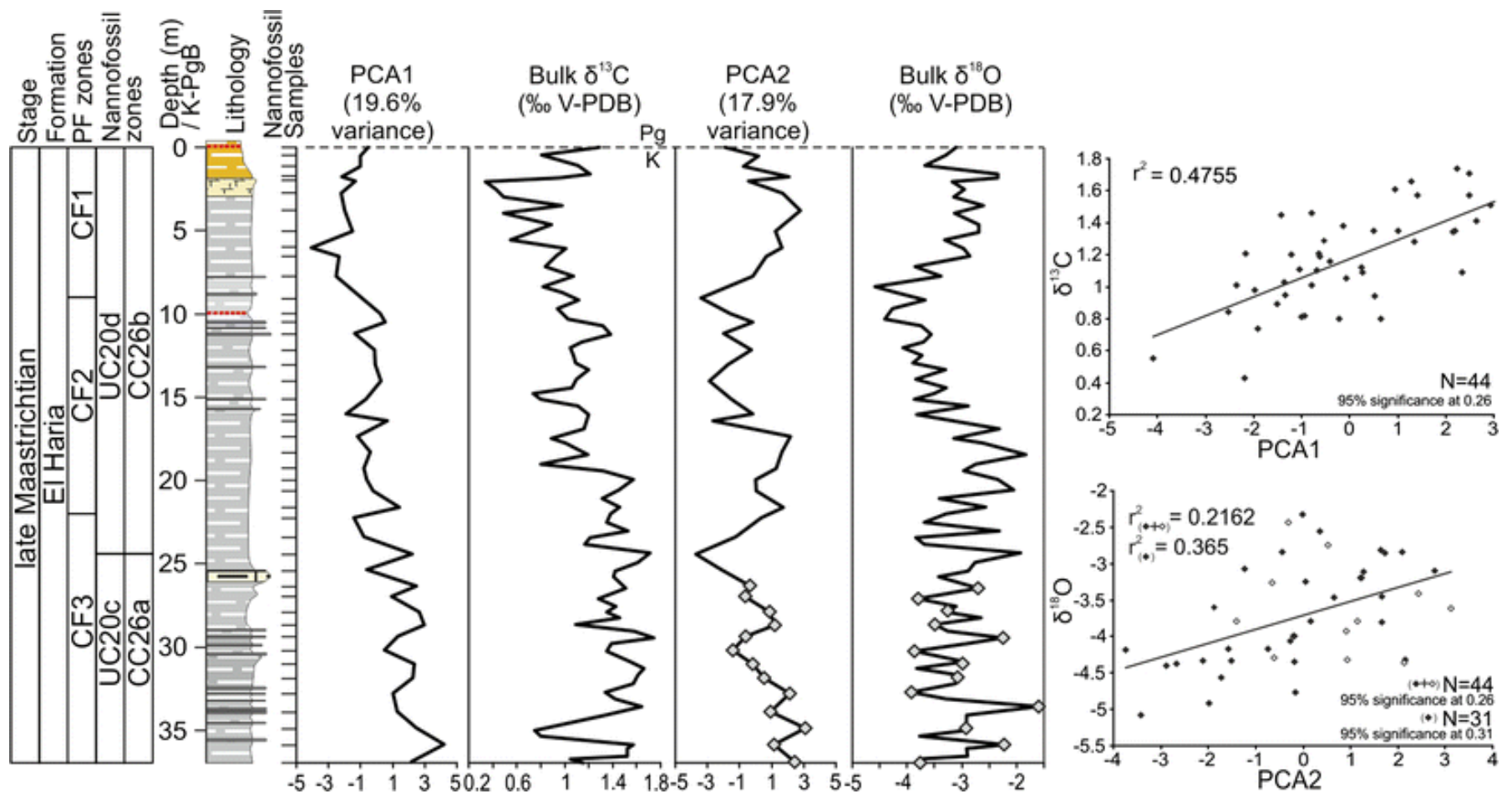

Fig. 11 : Comparison of PCA factors 1 and 2 with the bulk $\delta^{13} \mathrm{C}$ and $\delta^{18} \mathrm{O}$

PCA factor 1 (19.6\% of the variance) is characterized by high positive component loadings of $D$. rotatorius, Lithraphidites spp., P. stoveri and Retecapsa spp. and by high negative component loadings of Staurolithites spp. and Micula spp. (Table 1). Variations of PCA factor 1 show a progressive decrease from the base of the section to reach a minimum at $-6 \mathrm{~m}$. Values remain steadily low in the last $6 \mathrm{~m}$ of the Maastrichtian. Although the drop of PCA factor 1 values is not stepwise as for the bulk $\delta^{13} \mathrm{C}$, there is a highly significant positive 
correlation between these two factors $\left(r^{2}\right.$ of 0.47 as compared to a $95 \%$ significance level of 0.26 ) (Fig. 11). PCA factor 2 (17.8\% of the variance) is characterized by high component loadings of Ahmuellerella regularis, Zeugrhabdotus spp. and Rhagodiscus spp. and by high negative component loadings of $W$. barnesiae, $C$. ehrenbergii and Micula spp. $D$. rotatorius and Retecapsa spp appear to have somewhat significant positive and negative loadings to PCA2, respectively (Table 1). Variations in PCA factor 2 highlight the two intervals of homogeneous gray marls by more positive values, and the most negative values are within the interval of marl-marly limestone alternations between -16.5 and $-7.7 \mathrm{~m}$. Variations in PCA factor 2 resemble the trends in bulk $\delta^{18} \mathrm{O}$, from $-24 \mathrm{~m}$ to the $\mathrm{K}-\mathrm{PgB}$ (Fig. 11). A positive trend appears on the $x-y$ plot of PCA2 and the $\delta^{18} \mathrm{O}$, but the coefficient of correlation is not significant while taking all data points into account (Fig. 11). This is due to an absence of covariation between the two factors in the interval below $-25.5 \mathrm{~m}$ (Fig. 11). When discarding data points from the interval below $-25.5 \mathrm{~m}$, the correlation coefficient between PCA2 and the $\delta^{18} \mathrm{O}$ increases and reaches a value beyond the $95 \%$ significance level, though not really high (Fig. 11).

Table 1 : Principal component analysis (PCA) factor loadings

\begin{tabular}{|c|c|c|c|}
\hline \multirow{2}{*}{ Species } & \multirow{2}{*}{ Group number } & PCA1 (19.6 \% variance) & \multirow{2}{*}{$\begin{array}{l}\text { PCA2 (17.8 \% variance) } \\
\text { Temperature/stress }\end{array}$} \\
\hline & & Fertility & \\
\hline A. cymbiformis & N1 & 0.01 & -0.12 \\
\hline A. regularis & N2 & -0.16 & 0.34 \\
\hline Chiastozygus spp. & N3 & -0.25 & 0.03 \\
\hline C. ehrenbergii & N4 & 0.22 & -0.34 \\
\hline D. rotatorius & N5 & 0.34 & 0.25 \\
\hline Eiffelithus spp. & N6 & -0.18 & 0.15 \\
\hline Lithraphidites spp. & N7 & 0.38 & 0.11 \\
\hline Microrhabdulus spp. & N8 & 0.20 & -0.09 \\
\hline Micula spp. & N9 & -0.34 & -0.29 \\
\hline Prediscosphaera spp. & N10 & 0.07 & 0.19 \\
\hline P. stoveri & N11 & 0.30 & 0.22 \\
\hline Rhagodiscus spp. & N12 & -0.22 & 0.29 \\
\hline Retecapsa spp. & N13 & 0.28 & -0.26 \\
\hline Staurolithites spp. & N14 & -0.41 & 0.14 \\
\hline W. barnesiae & N15 & -0.14 & -0.47 \\
\hline Zeugrhabdotus spp. & N16 & 0.04 & 0.30 \\
\hline
\end{tabular}

The most significant loadings of each PCA factor are highlighted in bold.

The very high number of specimens counted for each slide allowed the investigation of relative abundance changes of rare to very rare species whose ecology has been well constrained in the past. The relative abundance of the well-established warm-water species Micula murus and the sum of cool-water species (Thibault and Gardin 2006, 2007, 2010) is generally below $1 \%$ in samples of the investigated section, but the expanded number of specimens counted to establish variations in the abundance of these taxa allowed the recording of reliable distinctive patterns (Fig. 12). The relative abundance of Micula murus 
starts increasing slightly at $-21.9 \mathrm{~m}$ but remains variable and below $0.8 \%$ in the lowermost part of the record (Fig. 12). At $-16.2 \mathrm{~m}$, an abrupt increase up to $1.4 \%$ is recorded in concordance with the decrease in bulk $\delta^{18} \mathrm{O}$. Values remain higher around $1 \%$ up to $-6.5 \mathrm{~m}$ where they abruptly drop. The relative abundance of $M$. murus remains low (below $0.3 \%$ up to $-1.5 \mathrm{~m}$ where it sharply increases again over $1.5 \%$ in conjunction with a sharp negative peak in bulk $\delta^{18} \mathrm{O}$ and lower values in PCA2 (Fig. 12). Cool-water taxa have a very low abundance, generally well below $0.5 \%$ in this southwestern Tethys assemblage. Three intervals with a positive peak in abundance of cool-water taxa can be highlighted at $-22.3 \mathrm{~m}$ $(0.8 \%),-20$ to $-18.5 \mathrm{~m}(0.9 \%)$ and $-5 \mathrm{~m}$ (up to $2.5 \%)$. Although these abundances are low, countings were performed over 500 specimens, and such peaks thus represent a meaningful increase from background values where 1-2 specimens only were observed to 4-5 specimens or more. Those three peaks occur in conjunction with higher positive values in PCA2 and the bulk $\delta^{18} \mathrm{O}$ (Fig. 12).

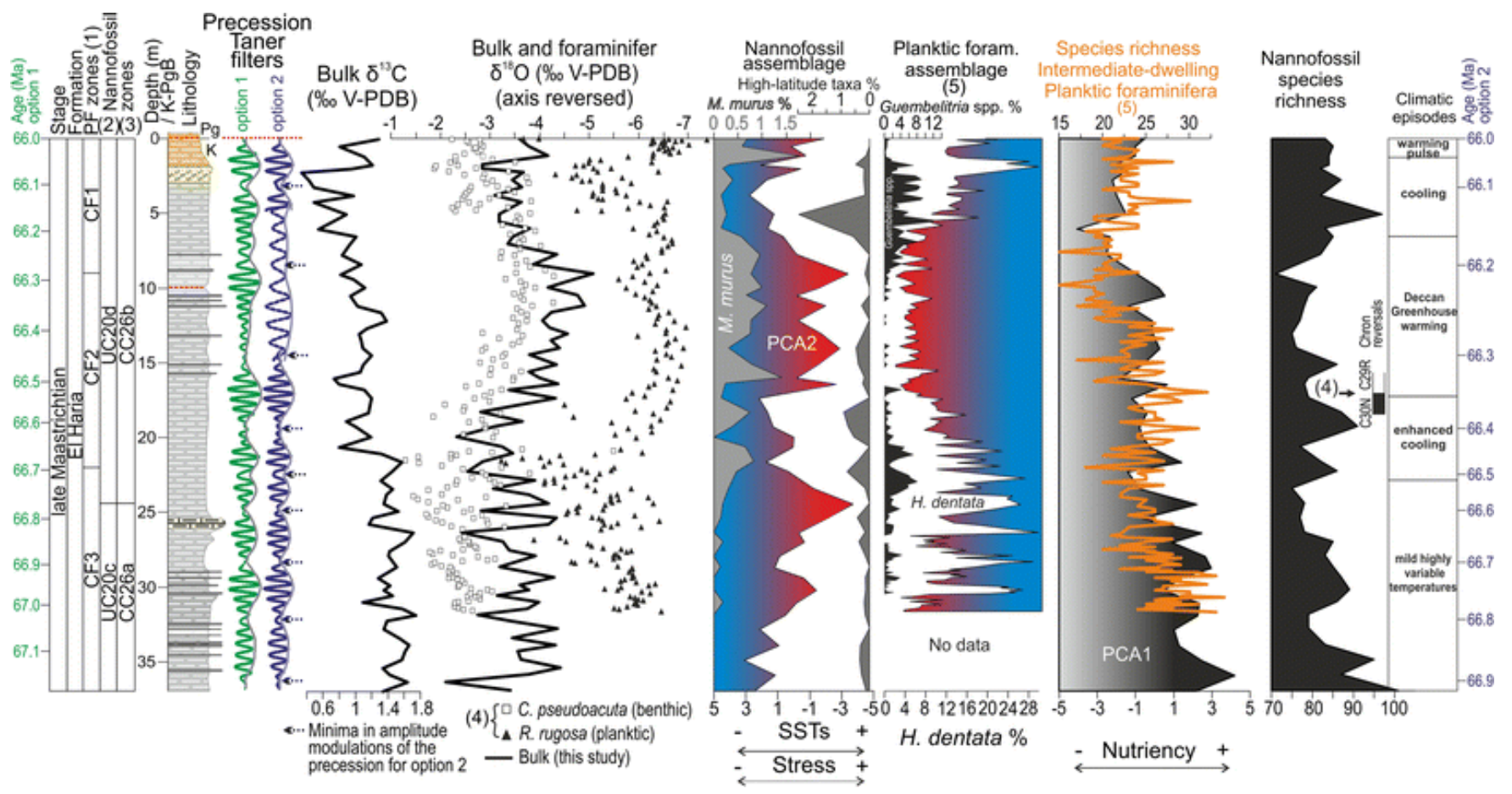

Fig. 12 : Summary of the main paleoceanographic events during the last $900 \mathrm{kyr}$ of the Cretaceous in the southwestern Tethys. (1) PF zones after Abramovich and Keller (2002). (2) Zonation of Burnett (1998). (3) Zonation of Perch-Nielsen (1985). (4) After Stüben et al. (2003). (5) After Abramovich and Keller (2002)

\section{Discussion}

\section{Validation of the age model and ages of important stratigraphic horizons}

The cyclostratigraphic tuning allowed plotting of the $\delta^{13} \mathrm{C}$ and MS signals in the time domain for the two different options (Fig. $5 \mathrm{bis}$ ). Worldwide correlation of bulk carbon-isotopic trends has proved to be a particularly powerful stratigraphic tool for the Maastrichtian stage (Thibault et al. 2012a, b; Voigt et al. 2012; Wendler 2013), and a high-resolution reference bulk carbonisotope curve, tied to an astronomical timescale, is available for the late Maastrichtian of the Zumaia section, Spain (Batenburg et al. 2012). In addition, MS variations were also measured 
with a high resolution at Zumaia and are reported here on the same timescale (in kyr before the $\mathrm{K}-\mathrm{PgB}$, Figs. $\underline{7}, \underline{8}$ ). Plotting of the Elles and Zumaia $\delta^{13} \mathrm{C}$ and $\mathrm{MS}$ records are shown on the same timescale for both options (Figs. $\underline{7}, \underline{8}$ ). None of the two options appears to show a perfect match for either $\delta^{13} \mathrm{C}$ or the MS signal, but overall, some of the long-term trends and the range of values of the bulk $\delta^{13} \mathrm{C}$ are comparable between Zumaia and Elles. The range of values is clearly different for the MS signal between the two sections, but long-term trends also appear to match with respect to the relative position of minima and maxima in option 2 (Fig. 8). Batenburg et al. (2012) found maxima of long-eccentricity cycles $\mathrm{Ma}_{405} 1$ and $\mathrm{Ma}_{405} 2$ in the MS signal of Zumaia at 166 and $568 \mathrm{kyr}$, respectively (Fig. 8). In option 2, these findings match well the interpreted $405 \mathrm{kyr}$ maxima of the $33 \%$ robust weighted average of the Elles MS signal at 187 and $550 \mathrm{kyr}$ for $\mathrm{Ma}_{405} 1$ and $\mathrm{Ma}_{405} 2$, respectively (Fig. 8 ). On the contrary, in option 1, it is rather difficult to reconcile the long-term trends between the two MS signals as a minimum of the Zumaia $405 \mathrm{kyr}$ filter correlates at ca. $750 \mathrm{kyr}$ to a maximum of the $33 \%$ robust average of the Elles MS signal (Fig. $\underline{7}$ ).

Option 2 is also in agreement with the age-model interpretation of Stüben et al. (2003). Biostratigraphic correlations between the Elles section and DSDP Site 525A suggest that the middle of planktic foraminifer zone CF2 corresponds roughly to the base of Chron C29r (Li and Keller 1998b; Stüben et al. 2003). The supposed position for the base of Chron C29r obtained through biostratigraphic correlation by the latter authors is reported here in Fig. 12 at ca. $-17 \mathrm{~m}$. This level corresponds almost exactly to the base of the negative $\delta^{18} \mathrm{O}$ excursion and is only about $1 \mathrm{~m}$ below the base of the acme of Micula murus, the both events having been proved to be nearly concomitant to the base of C29r in several other sections (Thibault and Gardin 2006, 2007, 2010). The duration of the Cretaceous part of C29r has been constrained through cyclostratigraphy in a number of studies with similar durations ranging between 300 and $370 \mathrm{kyr}$ (Herbert et al. 1995; Herbert 1999; Westerhold et al. 2008; Batenburg et al. 2012; Husson et al. 2011, 2014b). In addition, new U-Pb radiometric datings obtained from intertrappean ash layers in India constrain the base of chron C29r at $66.288 \pm 0.027 \mathrm{Ma}$ (Schoene et al. 2015), whereas the age of the K-Pg boundary has been recently dated at $66.043 \pm 0.086 \mathrm{Ma}$ (Renne et al. 2013). Taking the uncertainties of these two ages into account constrains the duration of the Cretaceous part of C29r to $245 \pm 113 \mathrm{kyr}$. The supposed stratigraphic position for the base of C29r at Elles corresponds to ca. $-525 \mathrm{kyr}$ below the $\mathrm{K}-\mathrm{PgB}$ in option 1 and $-350 \mathrm{kyr}$ in option 2 (Fig. 12). Therefore, option 1 falls outside the range of possibilities previously mentioned, whereas option 2 is in accordance with past cyclostratigraphic studies and with the upper range of the estimation obtained from recent radiometric datings.

Ages of important stratigraphic horizons have been derived from the two cyclostratigraphic options (Table 2). Age uncertainties due to the sampling resolution are generally below $5 \mathrm{kyr}$, except for the FO of Micula prinsii (15 kyr). An additional $15 \mathrm{kyr}$ uncertainty is accounted for the slightly discrepant durations of the time series while considering the different filters. These ages are compared to previously published estimations corrected with an age of $66 \mathrm{Ma}$ for the $\mathrm{K}-\mathrm{PgB}$ (Table 2). The age obtained for the base acme of Micula murus fits better to previous estimations in option 2 than in option 1 (Table 2). The age obtained for the FO of Micula prinsii points in both options to a very early age as compared to numerous previous records of this bio-horizon near the base of chron C29r, i.e., ca. $350 \mathrm{kyr}$ before the K-PgB (Henriksson 1993; Thibault and Gardin 2006, 2007, 2010; Gardin et al. 2012; Thibault et al. 2012b). However, Hennebert (2012) provided an early age of $834 \pm 142 \mathrm{kyr}$ before the K-PgB for the FO of M. prinsii in the nearby Tunisian Ain Settara section, and Norris et al. (1998) reported a very early age of ca. $1 \mathrm{Ma}$ before the $\mathrm{K}-\mathrm{PgB}$ for this bio-horizon within the upper part of chron C30n in the northwestern Atlantic. In addition, option 1 points to relatively minor changes in sedimentation rate. On the contrary, option 2 points to an increase in sedimentation rate 
concomitant to the main negative $\delta^{18} \mathrm{O}$ excursion and the increase in Micula murus, which is concordant with a strong influence of climate on burial rate (Fig. 13).

Table 2: Depth with respect to the Cretaceous-Paleogene boundary and estimated ages of important bio-horizons derived from the cyclostratigraphic analysis at Elles, compared with other published records

(1) Hennebert (2012), (2) Li et al. (2000),

(3) Gardin et al. (2012), (4) Pardo et al. (1996), (5) Thibault and Gardin (2006), (6) Thibault and Gardin (2007), (7) Thibault and Gardin (2010), (8) Norris et al. (1998)

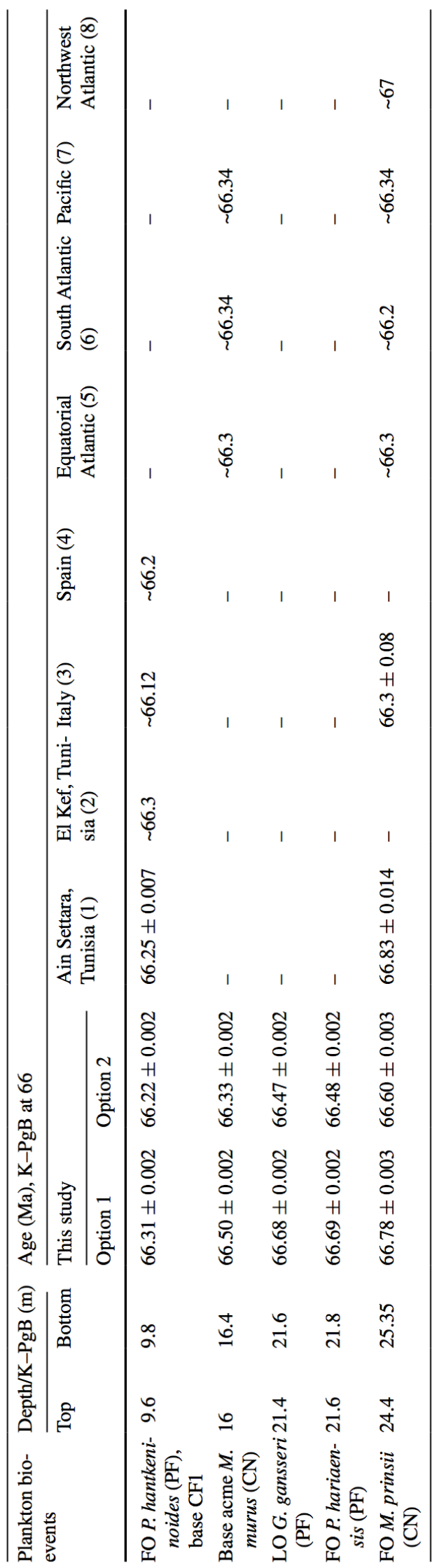




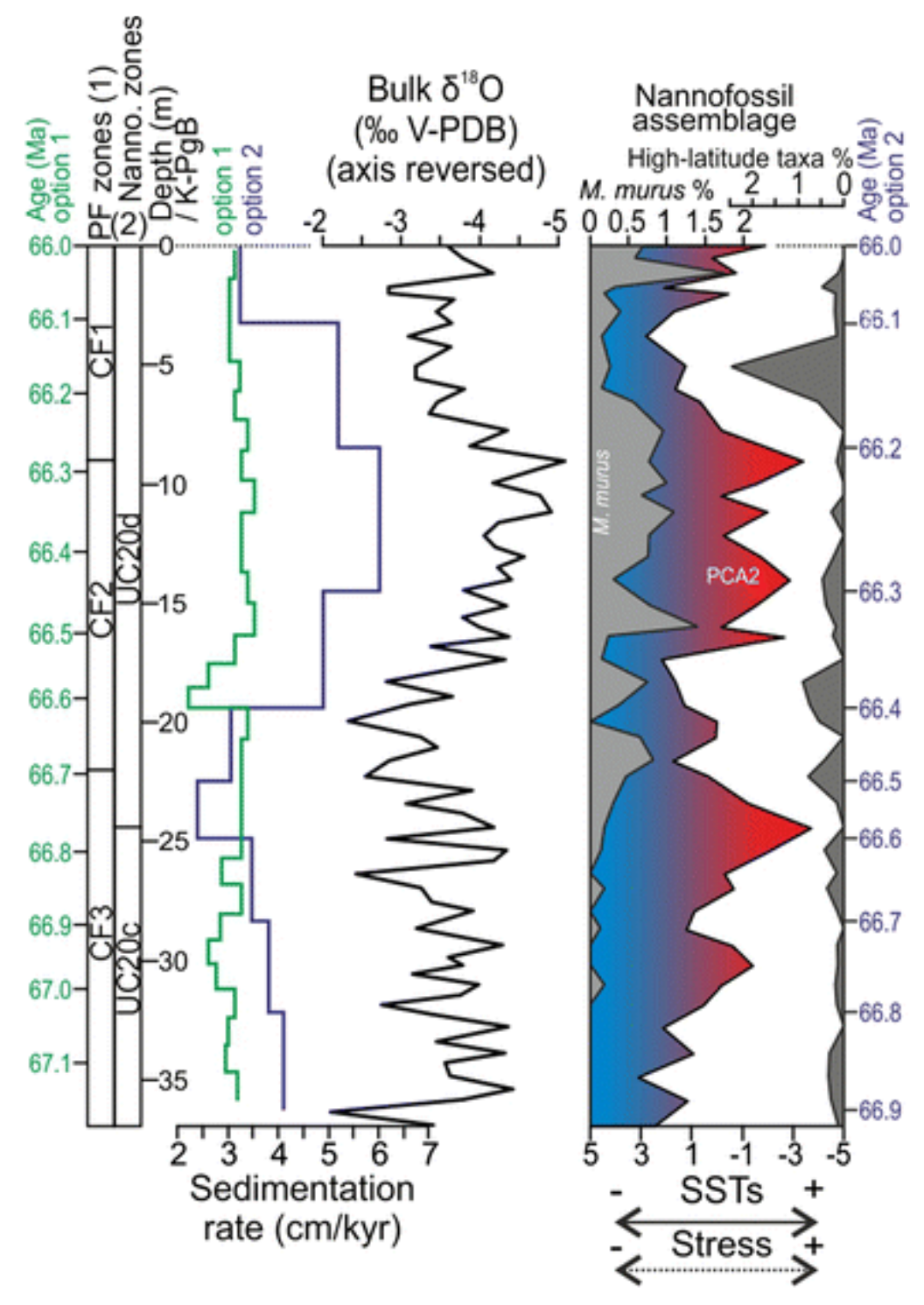

Fig. 13: Comparison of the variations in sedimentation rate obtained from the cyclostratigraphic options 1 and 2 with the bulk $\delta^{18} \mathrm{O}$ and significant temperatures changes expressed in the calcareous nannofossil assemblage

Finally, both age models highlight the expression of sub-Milankovitch frequencies which are coherent with semi-precessional cycles (Fig. 6). Similar sub-Milankovitch cycles have been detected throughout the Phanerozoic (Hagelberg et al. 1994; Rodriguez-Tovar and PardoIguzquiza 2003; Reuning et al. 2006; Boulila et al. 2010; De Vleeschouwer et al. 2012; Wu et al. 2012). This periodicity may result from a nonlinear response of the climate system to precession forcing at low latitudes, but the exact nature of these cycles remains a matter of debate (Hagelberg et al. 1994; Berger and Loutre 1997; Tuenter et al. 2003; Berger et al. 2006; Sun and Huang 2006; Tuenter et al. 2007; de Winter et al. 2014).

Calcareous nannofossil paleoecology and significance of PCA factors

A number of nannofossil taxa have been clearly ascertained as indices of paleotemperature and/or paleofertility of surface waters. In the Late Cretaceous, clear paleobiogeographic distribution patterns and paleoceanographic studies point to a non-questionable affinity of Ahmuellerella octoradiata, Gartnerago spp., Kamptnerius magnificus and Nephrolithus frequens to high-latitude cool surface waters (Thierstein 1981; Lees 2002), of Micula murus to 
tropical warm surface waters (Thierstein 1981; Thibault and Gardin 2006, 2007, 2010), and of Watznaueria barnesiae to warm oligotrophic surface waters (Thierstein 1981; Roth and Krumbach 1986; Erba et al. 1992; Williams and Bralower 1995; Watkins et al. 1996; Fisher and Hay 1999; Lees 2002; Watkins and Self-Trail 2005; Thibault and Gardin 2007; Sheldon et al. 2010). Biscutum spp., Zeugrhabdotus erectus and Discorhabdus rotatorius have been systematically associated with high fertility (Premoli Silva et al. 1989; Erba 1992; Erba et al. 1992; Williams and Bralower 1995; Fisher and Hay 1999). In the Maastrichtian of the North German Basin, increasing percentages of Prediscosphaera stoveri and Lithraphidites spp. were interpreted as reflecting increasing surface-water productivity (Friedrich et al. 2005). A similar paleoecological affinity was assigned to $P$. stoveri in the late Maastrichtian of the equatorial and south Atlantic (Thibault and Gardin 2006, 2007). Zeugrhabdotus spp. are considered as mesotrophic taxa (Erba et al. 1992; Thibault and Gardin 2006, 2007; Linnert and Mutterlose 2009; Linnert et al. 2011) and appear to show a preference to cool waters (Mutterlose and Kessels 2000; Tantawy 2008). Micula decussata is a cosmopolitan species whose dominance and increasing abundances have been associated with lowered surface productivity and high-stress environmental conditions (Eshet et al. 1992; Gardin and Monechi 1998; Tantawy 2003; Thibault and Gardin 2006). However, this taxon is also ten times more resistant to dissolution than any other nannofossil species (Thierstein 1980). Therefore, interpretation of the abundance trends of this species must be done with caution and careful assessment of the preservation. Neat paleoecological affinities of other Late Cretaceous nannofossil taxa are generally more difficult to establish because many species responded at the same time to temperature and nutriency as well as to potential salinity changes, whereas others were euryoecious taxa with a broad variety of ecological living conditions and opportunistic behavior, increasing in abundance under stressful conditions. The paleoecology of Cribrosphaerella ehrenbergii, Ahmuellerella regularis and of Maastrichtian representatives of the genera Retecapsa, Staurolithites and Rhagodiscus is poorly constrained. Cribrosphaerella ehrenbergii was a cosmopolitan species, common at both low and high latitudes (Lees 2002). Erba et al. (1995) associated blooms of C. ehrenbergii in Campanian lagoonal nannofossil assemblages to increased surface-water productivity, whereas Linnert et al. (2011) argued that these blooms of $C$ ehrenbergii were rather the expression of extreme salinity changes and stressful conditions of lagoonal settings. Linnert et al. (2011) argued instead for an oceanic affinity of $C$. ehrenbergii and showed a negative correlation between this species and fertile taxa. The paleoecology of Ahmuellerella regularis has never been discussed so far. This cosmopolitan species is rare to frequent at both low and high latitudes (Lees 2002). Ahmuellerella octoradiata, the sister species of this genus, is, however, a coolwater taxon (Thierstein 1981; Lees 2002). Elevated abundances of Retecapsa spp. were observed in both high and low-fertility settings (Hardas and Mutterlose 2007; Tiraboschi et al. 2009; Linnert et al. 2010, 2011). Linnert et al. (2011) thus consider this taxon as euryoecious, whose abundance is mainly controlled through the competition with other taxa, possibly increasing at times of stressful conditions when the nutrient content is either very low or elevated. In the Cenomanian-Turonian, Staurolithites crux is considered as a mesotrophic species (Hardas and Mutterlose 2007, Hardas et al. 2012), but this taxon is generally absent in the Maastrichtian and other representatives of the Staurolithites genus are rather considered as low-productivity indicators (Eshet and Almogi-Labin 1996). Valanginian to Late Cenomanian representatives of Rhagodiscus (mainly $R$. asper) have been associated with sea-surface warming (Mutterlose 1991, 1992; Kessels et al. 2006; Hardas et al. 2012), but the paleoecology of Turonian to Maastrichtian Rhagodiscus species has never been discussed so far and remains unconstrained.

In light of the literature, the establishment of nannofossil temperature and fertility indices is strictly dependent on the environmental setting in which species were thriving and cannot 
always be applied the same way in different paleoenvironmental situations and time slices (Lees et al. 2005). Although PCA analysis is an objective statistical method that helps extracting potential paleoecological information from the studied assemblage, the results obtained here are not completely straightforward as fertility, temperature, salinity and stressful conditions may sometimes covary. The low-fertility species Prediscosphaera cretacea (Eshet and Almogi-Labin 1996; Hardas et al. 2012) constitutes 10 to $15 \%$ of the assemblage but shows no significant changes through the profile and low loadings on the PCA axis. This species is not particularly affected by environmental changes in the Elles section (Fig. 10). High positive loadings of $D$. rotatorius, Lithraphidites spp. and $P$. stoveri accompanied by high negative loadings of Staurolithites spp. and Micula spp. to PCA1 suggest that this factor mainly represents variations in the fertility of surface waters (Table 1; Fig. 14). Very high negative loadings of $W$. barnesiae to PCA2 may suggest here a strong influence of surfacewater warming as the abundance of this taxon does not appear to be related to fertility factor PCA1 (Fig. 14). Contrariwise, high positive loadings of $A$. regularis and Zeugrhabdotus spp. may thus account for surface-water cooling (Fig. 14). However, the significant negative loadings of $C$. ehrenbergii and Micula spp. and to a lesser degree of Retecapsa spp. to PCA2 suggest that this factor is not only controlled by temperature but also shows a response to environmental stress (Fig. 14). Low values in PCA2 are thus interpreted here as a complex response of the calcareous nannofossil assemblage to increasing environmental stress accompanying surface-water warming. This interpretation may also explain why the correlation between PCA2 and the bulk $\delta^{18} \mathrm{O}$ is not completely straightforward, particularly in the interval below $-25.5 \mathrm{~m}$ (Fig. 11). The significant positive loadings of Rhagodiscus spp. to PCA2 may suggest that this species preferred either cooler waters or was unable to compete with other species during periods of environmental stress accompanying the warming (Fig. 14). The correlation between PCA2 and the bulk $\delta^{18} \mathrm{O}$, the negative correlation between the long-term trends of PCA2 and the relative abundance of the warm-water Micula murus from $-20 \mathrm{~m}$ to the $\mathrm{K}-\mathrm{Pg}$ boundary, as well as the three positive peaks in cool-water taxa observed in conjunction with higher positive values in PCA2 and in the bulk $\delta^{18} \mathrm{O}$ suggest a control of this factor by surface-water temperature (Fig. 12).

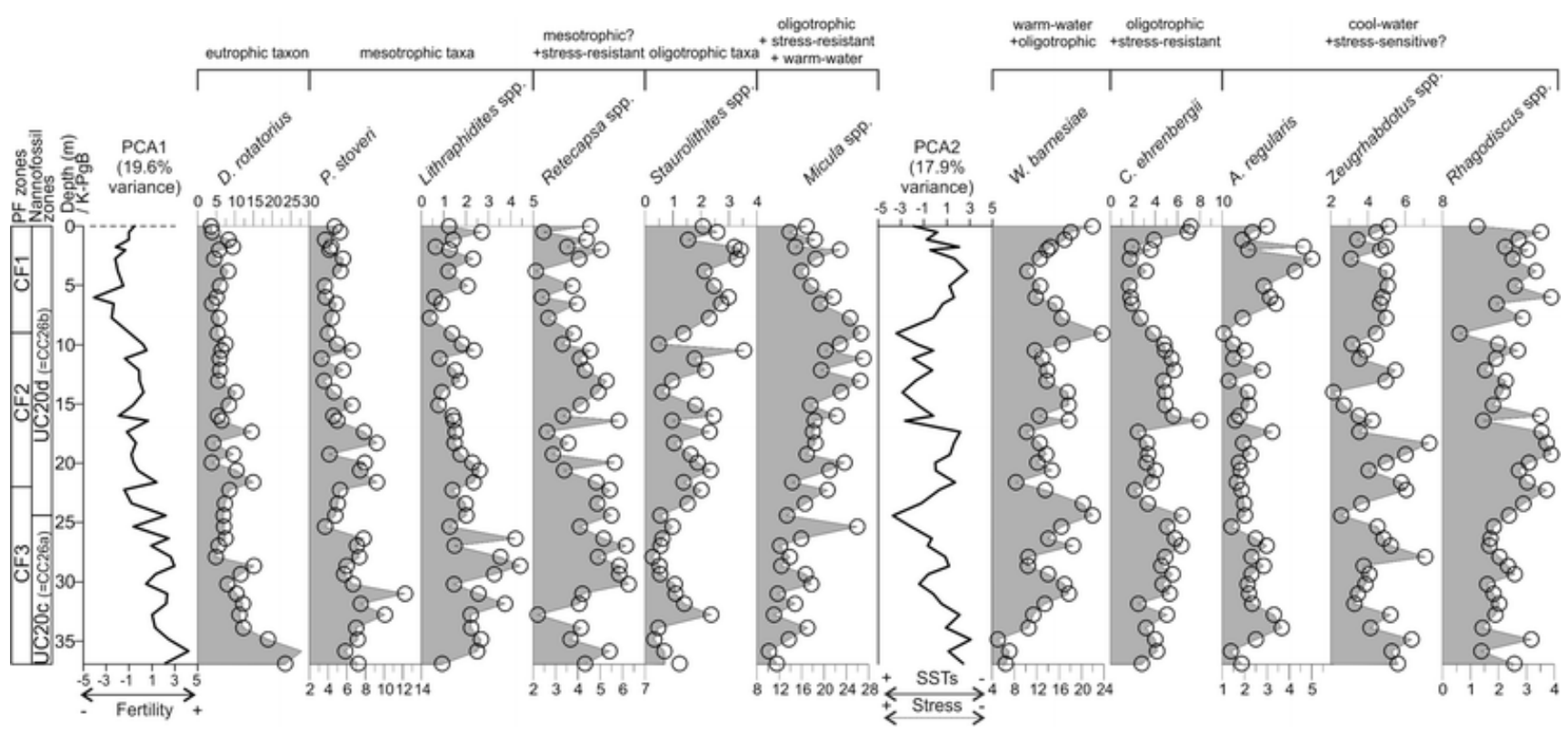

Fig. 14: Comparison of PCA factors 1 and 2 with the relative abundance of the most abundant calcareous nannofossil taxa with their inferred paleoecological preferences 


\section{Paleoceanographic significance of isotopic signals}

Stable isotopes performed on separated monospecific benthic and planktic foraminifers have long been favoured in paleoceanography over analyses of the bulk carbonate which represents a mixed signal (Grossman 2012). Geochemical information recorded by bulk carbonate must, however, not be neglected. As noted above, the calcareous nannofossils of Elles are abundant, well-preserved and present relatively few overgrown calcite of diagenetic origin. Calcareous rhombs of early diagenetic origin (Minoletti et al. 2004; Hermoso et al. 2009) are found in smear slides of the Elles section, but their abundance is extremely low. Given the location of Elles on an epicontinental shelf, the calcareous sedimentation was controlled by three components: calcareous nannofossils, planktic foraminifera and benthic foraminifera. Foraminifera constitute a very small fraction of the total carbonate in upper Cretaceous sediments (D'Hondt 2005). The contribution of carbonates produced by calcareous nannofossils is strikingly dominant over foraminifers in Elles samples. Complete foraminifer specimens are rather rare, and only few foraminifer fragments (i.e., isolated chambers, juvenile specimens and tests chips exhibiting second-order birefringence colors) are visible in smearslides ( $<1$ specimen per field of view). These findings are in agreement with the dominance of carbonates precipitated by calcareous nannoplankton in the photic zone in latest Cretaceous hemipelagic sedimentation (D'Hondt 2005; Minoletti et al. 2005). Isotopic ratios measured on bulk carbonates mainly represent those of calcareous nannofossil fractions as shown by Minoletti et al. (2005). Moreover, recent experiments have shown reduced interspecific differences and less offset in stable isotopes of small and large coccoliths with higher ambient carbon availability, which is expected in the seawater of periods with high $\mathrm{CO}_{2}$ concentrations (Rickaby et al. 2010; Moolna and Rickaby 2012). This finding has been confirmed for nannofossil fractions of past greenhouse conditions (Bolton et al. 2012). Consequently, bulk $\delta^{18} \mathrm{O}$ and $\delta^{13} \mathrm{C}$ values of well-preserved bulk carbonates may faithfully reflect trends in the primary isotopic composition of the Cretaceous sea-surface water. Bulk carbonate $\delta^{13} \mathrm{C}$ and $\delta^{18} \mathrm{O}$ values of the nearby El Kef section also correspond closely to values of the fine-fraction composed mainly of calcareous nannofossils (PerchNielsen et al. 1982). Diagenesis cannot be ruled out and may have shifted isotopic values to a slightly more negative range due to potential bottom water component in the very few early diagenetic rhombs observed in our slides. However, the correlation in isotopic variations and observed changes in the nannofossil assemblage suggest that trends are nicely preserved.

The relatively good correspondence of PCA factor 1 with the bulk $\delta^{13} \mathrm{C}$ could suggest that the nannofossil assemblage responded to fertility changes, and conversely, that carbon-isotopic trends may be interpreted here in terms of paleoproductivity (Fig. 12). Carbonate $\delta^{13} \mathrm{C}$ is mainly controlled by the global carbon cycle, which is in turn controlled by organic carbon burial, the mode of ocean circulation and the contribution into the marine realm of various external carbon species, such as terrestrial, platform-derived $\mathrm{C}_{\text {org }}$ and dissolved inorganic carbon, atmospheric $\mathrm{CO}_{2}$ or methane-derived carbon (Kump and Arthur 1999; Friedrich et al. 2009; Wendler 2013). Contrary to numerous earlier intervals of the Mesozoic, the Maastrichtian is not a period of enhanced burial of organic matter as attested by the absence of any globally and/or supra-regionally distributed black shales. An important late Campanian to early Maastrichtian negative carbon-isotope excursion has been explained by a change in the mode of oceanic circulation shifting the main sources of intermediate and deep waters from low to high latitudes (Barrera and Savin 1999; Friedrich et al. 2009). This process was achieved by the end of the early Maastrichtian (Barrera and Savin 1999; Voigt et al. 2013), but weakening in high-latitude deep-water formation is also suggested in the middle Maastrichtian (Jung et al. 2013). Therefore, instability in the mode of the global oceanic circulation could also be evoked here for $\delta^{13} \mathrm{C}$ variations in the late Maastrichtian. Pulses of 
volcanically derived $\mathrm{CO}_{2}$ associated with Deccan volcanism would have contributed only to very small changes in the isotopic composition of the oceans (Kump and Arthur 1999). Late Maastrichtian variations in the marine $\delta^{13} \mathrm{C}$ of carbonates can thus be explained through changes in the burial of organic matter that may be triggered during the late Maastrichtian through sea-level changes, instability of the mode of oceanic circulation and/or changes in global productivity (Jarvis et al. 2002, 2006). The observed late Maastrichtian decrease in $\delta^{13} \mathrm{C}$ was previously associated to a global decrease in marine productivity (Li and Keller 1998a, $\underline{b}$, Thibault and Gardin 2010) and a parallel drop in nutriency is expressed in calcareous nannofossil assemblages in the Atlantic and Pacific Oceans (Thibault and Gardin 2006, 2007, 2010). The local drop in nutriency observed in the Elles section thus coincides with similar drops in the Atlantic and Pacific Oceans. These findings support a global decrease in marine productivity as the most likely explanation for the late Maastrichtian global decrease in the marine $\delta^{13} \mathrm{C}$ of carbonates, although an influence on this proxy of potential changes in sea level and sources of deep-water formation cannot be entirely ruled out.

Bulk carbonate $\delta^{18} \mathrm{O}$ trends agree relatively well with $\delta^{18} \mathrm{O}$ data on separated benthic and planktic foraminifers that thrive and calcify in bottom and surface waters, respectively (Fig. 12). Local influence of sea-level change on sedimentation of the Elles section was investigated by Stüben et al. (2003) by the use of the calcite/detritus ratio which reflects variations of the detrital influx. A possible influence of freshwater input on bulk and foraminifer $\delta^{18} \mathrm{O}$ values cannot be ruled out since periods of higher $\delta^{18} \mathrm{O}$ values correspond to lower $\mathrm{Ca}$ /detritus ratios suggesting lower sea levels (Stüben et al. 2003). These authors discarded this hypothesis because variations observed in benthic foraminiferal $\delta^{18} \mathrm{O}$ are similar to records of various oceanic basins and thus likely reflect a global climatic signal. An influence of freshwater input on the bulk $\delta^{18} \mathrm{O}$ cannot be ruled out here as there is a clear correlation between the carbonate content and the bulk $\delta^{18} \mathrm{O}$ of our samples (Fig. 9 ). Previously published data on foraminifer stable isotopes (Stüben et al. 2003) yield important results for comparison with the bulk (Fig. 12). Stüben et al. (2003) recognized that the low $\delta^{18} \mathrm{O}$ values of their planktic foraminifers may point to a non-negligible diagenetic overprint. They suggested, however, that trends may be well preserved. Isolated foraminifer chambers and juvenile foraminifer tests observed in our smear slides of Elles were almost completely filled with large calcite crystals of undoubtedly diagenetic origin. In addition, planktic foraminifer $\delta^{18} \mathrm{O}$ is on average $2.5 \%$ more negative than the bulk $\delta^{18} \mathrm{O}$ (Fig. 12). The difference between benthic and planktic foraminiferal $\delta^{18} \mathrm{O}\left(\Delta \delta^{18} \mathrm{O}\right.$ planktic-benthic) of latest Maastrichtian subtropical South Atlantic DSDP Sites 525 and 528 is of $0.5 \%$ for a paleodepth of $300-500 \mathrm{~m}$ (Barrera and Savin 1999). The average difference between benthic foraminiferal and bulk $\delta^{18} \mathrm{O}$ at Elles is of $0.4 \%$ for a paleodepth of $100-150 \mathrm{~m}$ (Fig. 12). In contrast, the $\Delta \delta^{18} \mathrm{O}$ planktic-benthic of Elles is on average $>2 \%$ and up to $4 \%$ which appears quite unrealistic (Fig. 12). As a consequence, it is likely that the $\delta^{18} \mathrm{O}$ of planktic foraminifers in the Elles section is strongly affected by diagenesis. This interpretation can explain the large differences in the range of values obtained for the bulk isotopes and for planktic foraminifers but also the lack of match in some of the long-term trends of these two signals such as: (1) the slight positive excursion observed in planktic foraminifer $\delta^{18} \mathrm{O}$ concomitant to the most negative values of the bulk between -11 and $-8 \mathrm{~m}$ (Fig. 12), (2) the negative excursion observed in planktic foraminifer $\delta^{18} \mathrm{O}$ between -8 and $-4 \mathrm{~m}$ concomitant to a progressive increase in the bulk and in benthic foraminifer $\delta^{18} \mathrm{O}$ (Fig. 12). Finally, contrary to the trends observed in the planktic foraminifer $\delta^{18} \mathrm{O}$, the trends observed in the bulk $\delta^{18} \mathrm{O}$ match well those delineated in the benthic foraminifer $\delta^{18} \mathrm{O}$, suggesting that the same climatic changes affected in a similar fashion the entire water column (Fig. 12). This finding supports that the benthic foraminiferal $\delta^{18} \mathrm{O}$ was not severely affected by diagenesis, contrary to that of planktic foraminifers. It has long been recognized that diagenetic alteration of foraminiferal calcite is much less problematic in 
benthic than in planktic foraminifera and that extensive recrystallization of benthic foraminiferal calcite generally results in minimal shifts from primary $\delta^{18} \mathrm{O}$ and $\delta^{13} \mathrm{C}$ values (Edgar et al. 2013). Consequently, we believe that the bulk $\delta^{18} \mathrm{O}$ signal of Elles reflects much better the primary composition of the photic zone than planktic foraminiferal $\delta^{18} \mathrm{O}$ and that the $\delta^{18} \mathrm{O}$ gradient between surface and deep waters is much lower than previously suggested from results of Stüben et al. (2003). This interpretation is also supported by the shallow setting of the Elles section. However, a small imprint of an early diagenetic bottom water signature and changes in the freshwater input may also have had some influence on bulk $\delta^{18} \mathrm{O}$, and although trends appear reliable, neither this proxy nor planktonic foraminifer $\delta^{18} \mathrm{O}$ values is likely to represent faithfully primary sea-surface-water values.

\section{Paleoceanographic changes in the southwestern Tethys for the last $900 \mathrm{kyr}$ of the Cretaceous}

As discussed above, biostratigraphic correlation of the Elles section to other records favors option 2 as a reasonable interpretation of the cyclostratigraphic analysis. Paleoceanographic changes unravelled from this section are presented in this chapter with respect to the age scale derived from option 2. Combination of the observed trends in PCA2, in the relative abundance of Micula murus and high-latitude taxa and in the bulk $\delta^{18} \mathrm{O}$ indicates: (1) mild highly variable sea-surface paleotemperatures from 66.9 to $66.52 \mathrm{Ma}$, (2) an enhanced cooling event between 66.52 and $66.35 \mathrm{Ma}$, (3) a pronounced warming event between 66.35 and 66.16 Ma, (4) cooling between 66.16 and 66.03 and (5) a short warming pulse in the last $30 \mathrm{kyr}$ of the Cretaceous (Fig. 12). The highly variable climatic interval at the base of the section is characterized by a high variability in the nannofossil total abundance. Within the two pronounced cooling episodes, nannofossil total abundance is lower and species richness is higher (Fig. 2). This could indicate that relatively cool climate modes generally favoured more diversified, low growth rate, specialized K-strategists, while warmer climate modes, possibly accompanied with stressful conditions, favoured less diversified, blooming ecologic generalists such as Micula spp.

Benthic foraminifer $\delta^{18} \mathrm{O}$ data delineate similar trends, whereas planktic foraminiferal $\delta^{18} \mathrm{O}$ exhibits slightly different fluctuations, particularly within the last $300 \mathrm{kyr}$ of the Maastrichtian (Fig. 12). This can be explained by a potential diagenetic overprint of planktic foraminiferal values but also by the fact that most planktonic foraminifer species of the CampanianMaastrichtian occupied a subsurface mixed layer rather than surface waters (Abramovich et al. 2003). In contrast, most nannofossil species of the Maastrichtian were restricted to surface waters. As is the case in this study, Maastrichtian bulk-rock $\delta^{18} \mathrm{O}$ signals of pure nannofossil carbonates and nannofossil fractions that did not undergo intense diagenetic alteration might actually better reflect sea-surface temperatures than the existing record of planktic foraminifera at Elles. The main greenhouse warming event is also marked by a significant drop in the relative abundance of the intermediate-dwelling PF Heterohelix dentata (Fig. 12). The drop of this ecologic generalist species has been interpreted as a response to environmental stress accompanying the warming episode (Abramovich and Keller 2002). Surprisingly, blooms of the opportunistic PF Guembelitria spp. occur at Elles within the cooling events at 66.52-66.35 Ma and at 66.16-66.03 Ma (Fig. 12).

Important changes in nutriency of the water column occured during the last $900 \mathrm{kyr}$ of the Maastrichtian. A decrease in PCA1 is indicative of a drop in surface-water nutriency from 66.9 to $66.16 \mathrm{Ma}$ (Fig. 12). This is accompanied by a stepwise, progressive decrease in bulk $\delta^{13} \mathrm{C}$ from 66.9 to ca. $66.03 \mathrm{Ma}$. A return to slightly more positive values of the fertility index occurs in the last $160 \mathrm{kyr}$ of the Maastrichtian, whereas the bulk $\delta^{13} \mathrm{C}$ returns to more positive values only in the last $50 \mathrm{kyr}$ before the $\mathrm{K}-\mathrm{PgB}$. The overall good coupling between the two 
parameters and their similarity to contemporaneous records of other oceanic basins ( $\mathrm{Li}$ and Keller 1998a, $\underline{b}$, Thibault and Gardin 2006, 2007, 2010) suggests that the drop of marine primary productivity was the main controlling factor for variations in carbon isotopes. The trends in PCA1 parallel trends in the species richness of PF intermediate dwellers (Fig. 12). The diversity of surface and deep-dweller groups of PFs was relatively unaffected by climatic and productivity changes at Elles (Abramovich and Keller 2002). As suggested by these authors, PF intermediate dwellers may have been much more sensitive to changes in the nutriency of the water column because they inhabit the thermocline layer where food supply is generally the highest due to the recycling of nutrients from deeper waters. The parallel trends in PCA1 and the diversity of PF intermediate dwellers could thus be explained by changes in the depth of the nutricline layer. However, there is no clear link between fertility/intermediate dweller species richness and temperature changes. The first two coupled parameters remain relatively stable during the lower half of the end-Cretaceous warming and drop abruptly to reach minimum values at the transition between the warming and the following cooling event (Fig. 12). Therefore, in the Elles section, minima in surface-water nutriency and maximum stress within the group of PF intermediate dwellers occurred at the transition between the greenhouse warming and the end-Maastrichtian cooling. This episode of stress is also characterized by the increase in the relative abundance of the opportunist Guembelitria group (Abramovich and Keller 2002; Fig. 9) The relationship between nannofossil species richness, climate change and potential ecological stress is not straightforward. Few peaks and somewhat higher values in species richness are recorded during the cooling episodes (Fig. 12). The nannofossil diversity remained on average very high, $>80$ species until the very end of the Cretaceous.

\section{Replacing the Elles record in a global context}

The large increase in PCA2 and the acme of Micula murus recorded here at 66.35-66.16 Ma is similar to findings in the Tropical Pacific and in the Atlantic and correlates with the global expression of the end-Maastrichtian warming as expressed in the $\delta^{18} \mathrm{O}$ of benthic foraminifera and bulk carbonates (Barrera and Savin 1999; Thibault and Gardin 2010). Moreover, this episode correlates with an increase in atmospheric $\mathrm{pCO}_{2}$ calculated from the $\delta^{13} \mathrm{C}$ of paleosol carbonates in Texas (Nordt et al. 2003; Wilf et al. 2003). Several of the main biotic changes observed globally at the end of the Maastrichtian in planktic foraminifers are also coincident with this episode of warming. Among these changes, dwarfism of planktic foraminifers and increase in abundance of the opportunist Guembelitria group suggest stressful conditions associated with the greenhouse warming within chron $\mathrm{C} 29 \mathrm{r}$ of several tropical sections (Abramovich and Keller 2002, 2003; Abramovich et al. 2010). Blooms of the opportunist Guembelitria are also observed within biozone CF1, immediately prior to the K-PgB in Texas, Egypt, Israel and India (Keller et al. 2012; Punekar et al. 2014). Several authors suggested that the end-Maastrichtian warming was triggered by Deccan volcanism through the addition of greenhouse gas $\mathrm{CO}_{2}$ to the atmosphere (Dessert et al. 2001; Wignall 2001; Cohen and Coe 2002). Other studies suggested that the impact of $\mathrm{SO}_{2}$ degassing related to flood basalt volcanism would trigger short-term episodes of intense cooling and strong environmental instabilities (Chenet et al. 2005; Self et al. 2008).

There is thus few doubt that phase 2 of Deccan volcanism (the main Cretaceous phase as defined by Chenet et al. 2009), the end-Maastrichtian greenhouse warming and associated biotic perturbations start concomitantly very close to the C29r/C30n reversal (Li and Keller 1998a, b; Barrera and Savin 1999; Wilf et al. 2003; Keller et al. 2008; Robinson et al. 2009). The timing of the end-Maastrichtian warming obtained from the cyclostratigraphic interpretation of option 2 at Elles appears concordant with these past studies (Fig. 12). The 
short episode of cooling following the Deccan warming was also demonstrated in a number of previous studies (Li and Keller 1998b; Bernaola and Monechi 2007; Thibault and Gardin 2007, 2010). In the Elles record, cooling starts ca. $160 \mathrm{kyr}$ before the K-PgB, lasts for about 120-130 kyr, and is followed by an additional warming pulse in the last $30 \mathrm{kyr}$ of the Cretaceous (Fig. 12), in accordance with the previous interpretation of Stüben et al. (2003) and Punekar et al. (2014). This climatic evolution points to very rapid sea-surface temperature changes that could reflect the interplay between $\mathrm{CO}_{2}$ and $\mathrm{SO}_{2}$ injections from Deccan volcanism. It is thus likely that the environmental conditions preceding the $\mathrm{K}-\mathrm{PgB}$ triggered stress and extinctions prior to the bolide impact. Moreover, biotic perturbations seem to have been triggered during both the warming and cooling phases of the last $350 \mathrm{kyr}$ of the Cretaceous (Ward 1990; Abramovich and Keller 2002, Keller et al. 2012; Stinnesbeck et al. 2012; Tobin et al. 2012, 2014). These latter findings probably reflect the difficulty of biotic groups to adapt to these rapid climatic changes. As far as calcareous nannoplankton is concerned, the main changes occur in association with the end-Maastrichtian greenhouse warming. A slight decline in species richness of this group is recorded during this episode in the tropical Pacific and in the South Atlantic (Thibault and Gardin 2010). However, nannofossil species richness returns to higher values in the following episode of cooling preceding the K$\mathrm{PgB}$ in the Pacific (Thibault and Gardin 2010). At Elles, the nannofossil species richness remains very high until the end of the Maastrichtian (Fig. 12). As shown in this study and in Thibault and Gardin (2006, 2007, 2010), calcareous nannofossils highlight a global drop in the nutriency of tropical surface waters in the late Maastrichtian (Fig. 12). However, in the present study and as in many sections worldwide (Pospichal 1996; Bown 2005; Jiang et al. 2010), the climatic fluctuations and environmental perturbations associated with Deccan volcanism had a relatively weak impact on the diversity of the calcareous nannoplankton community prior to the $\mathrm{K}-\mathrm{PgB}$ bolide impact.

Apparent contradictions in the modelled climatic effects of Deccan volcanism and in the response of different marine biological groups to the associated environmental perturbations point to a very complex scenario for the end-Cretaceous mass extinction. Unravelling the complexity of this scenario in the marine realm will only arise from cross-disciplinary studies of the different groups of the marine biota calibrated with cyclostratigraphy, recent time constraints from radiometric dating of the Deccan lava pile (Schoene et al. 2015), and the development of geochemical proxies of volcanism in marine sediments.

\section{Conclusions}

The integrated study of the Elles section has established a precise calendar of paleoenvironmental events in the southern Tethys for the last $900 \mathrm{kyr}$ preceding the $\mathrm{K}-\mathrm{PgB}$ :

- The cyclostratigraphic analysis of the Elles section, Tunisia, revealed a strong precessional forcing in MS variations with amplitude modulation by the eccentricity, and a well-expressed obliquity signal, allowing the building of an age model for the latest Maastrichtian of the southwestern Tethys.

- Variations in PCA2, subtle variations in abundances of cool-water taxa and the warm-water species Micula murus and variations in bulk carbonate and foraminifer $\delta^{18} \mathrm{O}$ point to a common paleoclimatic interpretation in Tunisia. Sea-surface paleotemperatures were generally cooler and highly variable between 66.9 and $66.35 \mathrm{Ma}$ with an enhanced cooling event recorded between 66.52 and $66.35 \mathrm{Ma}$. A major warming of sea-surface waters is recorded between 66.35 and $66.16 \mathrm{Ma}$ and reflects the expression of the worldwide endMaastrichtian greenhouse warming. Cooling resumed between 66.16 and $66.03 \mathrm{Ma}$. The last $30 \mathrm{kyr}$ of the Cretaceous is characterized by an additional short warming pulse. 
- The last $900 \mathrm{kyr}$ of the Cretaceous is characterized by a decrease in surface-water nutriency as indicated by the nannofossil assemblage through PCA1. This finding is similar to records of the Atlantic and Pacific Oceans which suggest that the concomitant global decrease in bulk $\delta^{13} \mathrm{C}$ could be caused by a drop in overall plankton productivity.

- The species richness of intermediate-dwelling planktic foraminifera (PF) parallels the trends in the nannofossil fertility index, indicating a direct link between the drop in surface-water nutriency and stressful environmental conditions within the nutricline. Maximum stress in PF and minimum nutriency occurred at the transition between the greenhouse warming and the end-Maastrichtian cooling.

- The $\delta^{13} \mathrm{C}$, the nannofossil fertility index and the species richness of intermediate-dwelling planktic foraminifera all returned to slightly more positive values during the last $160 \mathrm{kyr}$ of the Cretaceous suggesting a return to less stressful conditions.

- The nannofossil species richness tends to be lower during warming episodes, thus confirming that stressful conditions may have accompanied greenhouse warming pulses. However, the species richness remained very high throughout the last $900 \mathrm{kyr}$ of the Cretaceous.

\section{Acknowledgments}

Funding for this study was provided by Eclipse II Program and the Carlsberg Foundation. Warmly thanks to Chokri Yaich and Habib Bensalem for guidance in the field. We are grateful to Thierry Adatte and Christian Linnert for critical review, helpful suggestions and discussions of the manuscript.

\section{Electronic supplementary material}

Below is the link to the electronic supplementary material.

Supplementary material 1 (XLSX $48 \mathrm{~kb}$ )

\section{References}

1. Abramovich S, Keller G (2002) High stress late Maastrichtian paleoenvironment: inference from planktonic foraminifera in Tunisia. Palaeogeogr Palaeoclimatol 178:145-164

2. Abramovich S, Keller G (2003) Planktonic foraminiferal response to the latest Maastrichtian abrupt warm event: a case study from South Atlantic DSDP Site 525A. Mar Micropaleontol 48:225-249

3. Abramovich S, Keller G, Stüben D, Berner Z (2003) Characterization of late Campanian and Maastrichtian planktonic foraminiferal depth habitats and vital activities based on stable isotopes. Palaeogeogr Palaeoclimatol 202:1-29

4. Abramovich S, Yovel-Corem S, Almogi-Labin A, Benjamini C (2010) Global climate change and planktic foraminiferal response in the Maastrichtian. Paleoceanography. doi:10.1029/ 2009PA001843

5. Adatte T, Keller G, Stinnesbeck W (2002) Late Cretaceous to early Paleocene climate and sea-level fluctuations: the Tunisian record. Palaeogeogr Palaeoclimatol 178:165-196

6. Alegret L, Thomas E, Lohmann KC (2012) End-Cretaceous marine mass extinction not caused by productivity collapse. Proc Natl Acad Sci USA 109:728-732

7. Barrera E, Savin SM (1999) Evolution of late Campanian-Maastrichtian marine climates and oceans. In: Barrera E, Johnson CC (eds) Evolution of the Cretaceous ocean-climate system. Geol Soc Am S 332:245-282

8. Batenburg SJ, Sprovieri M, Gale AS, Hilgen FJ, Hüsing S, Laskar J, Liebrand D, Lirer F, Orue-Etxebarria X, Pelosi N, Smit J (2012) Cyclostratigraphy and astronomical tuning of the 
Late Maastrichtian at Zumaia (Basque country, Northern Spain). Earth Planet Sc Lett 359360:264-278

9. Berger A, Loutre MF (1997) Intertropical latitudes and precessional and half-precessional cycles. Science 278:1476-1478

10. Berger A, Loutre MF, Mélice JL (2006) Equatorial insolation: from precession harmonics to eccentricity frequencies. Clim Past 2:131-136. doi:10.5194/cp-2-131-2006

11. Bernaola G, Monechi S (2007) Calcareous nannofossil extinction and survivorship across the Cretaceous - Paleogene boundary at Walvis Ridge (ODP Hole 1262C, South Atlantic Ocean). Palaeogeogr Palaeoclimatol 255:132-156

12. Bolton CT, Stoll HM, Mendez-Vicente A (2012) Vital effects in coccolith calcite: Cenozoic climate- $\mathrm{pCO}_{2}$ drove the diversity of carbon acquisition strategies in coccolithophores? Paleoceanography. doi:10.1029/2010PA001951

13. Boulila S, Galbrun B, Hinnov LA, Collin PY, Ogg JG, Fortwengler D, Marchand D (2010) Milankovitch and sub-Milankovitch forcing of the Oxfordian (Late Jurassic) terres noires formation (SE France) and global implications. Basin Res 22:717-732

14. Bown $P$ (2005) Selective calcareous nannoplankton survivorship at the Cretaceous-Tertiary boundary. Geology 33:653-656

15. Bralower T, Eccles L, Kutz J, Yancey T, Schueth J, Arthur M, Bice D (2010) Grain size of Cretaceous-Paleogene boundary sediments from Chicxulub to the open ocean: implications for interpretation of the mass extinction event. Geology 38:199-202

16. Burnett JA (1998) Upper Cretaceous. In: Bown P (ed) Calcareous nannofossil biostratigraphy. British Micropaleontology Society Publication Series. Chapman \& Hall/Kluwer Academic Publishers, London, pp 132-199

17. Burollet PF (1967) General geology in Tunisia. In: Martin L (ed) Guidebook to the geology history of Tunisia. Petroleum Exploration Society of Libya, 9th annual field conference, $p 67$

18. Chenet A-L, Fluteau F, Courtillot V (2005) Modelling massive sulphate aerosol pollution, following the large 1783 Laki basaltic eruption. Earth Planet Sci Lett 236:721-731

19. Chenet A-L, Courtillot V, Fluteau F, Gerard M, Quidelleur X, Khadri SFR, Subbarao KV, Thordarson $T$ (2009) Determination of rapid Deccan eruptions across the Cretaceous-Tertiary boundary using paleomagnetic secular variation: 2. Constraints from analysis of eight new sections and synthesis for a 3500-m-thick composite section. J Geophys Res Earth 114(B6). doi:10.1029/2008JB005644

20. Cohen AS, Coe AL (2002) New geochemical evidence for the onset of volcanism in the Central Atlantic magmatic province and environmental change at the Triassic-Jurassic boundary. Geology 30:267-270

21. D'Hondt S (2005) Consequences of the Cretaceous/Paleogene mass extinction for marine ecosystems. Annu Rev Ecol Evol Syst 36:295-317

22. de Vleeschouwer D, Da Silva AC, Boulvain F, Crucifix M, Claeys $P$ (2012) Precessional and half-precessional climate forcing of Mid-Devonian monsoon-like dynamics. Clim Past 8:337351. doi:10.5194/cp-8-337-2012

23. de Winter NJ, Zeeden C, Hilgen FJ (2014) Low-latitude climate variability in the Heinrich frequency band of the Late Cretaceous Greenhouse world. Clim Past 10:1001-1015. doi:10. 5194/cp-10-1001-2014

24.Dessert C, Dupre B, Francois LM, Schott J, Gaillardet J, Chakrapani G, Bajpai S (2001) Erosion of Deccan Traps determined by river geochemistry: impact on the global climate and the Sr-87/Sr-86 ratio of seawater. Earth Planet Sci Lett 188:459-474

25. Edgar KM, Pälike H, Wilson PA (2013) Testing the impact of diagenesis on the $\delta^{18} \mathrm{O}$ and $\delta^{13} \mathrm{C}$ of benthic foraminiferal calcite from a sediment burial depth transect in the equatorial Pacific. Paleoceanography 28:468-480 
26. Ellwood BB, Crick RE, Hassani AE, Benoist SL, Young RH (2000) Magnetosusceptibility event and cyclostratigraphy method applied to marine rocks: detrital input versus carbonate productivity. Geology 28:1135-1138

27. Erba $E$ (1992) Calcareous nannofossil distribution in pelagic rhytmic sediments (AptianAlbian Piobicco core, Central Italy). Riv Ital Paleontol Stratigr 97:455-484

28. Erba E, Castradori D, Guasti G, Ripepe M (1992) Calcareous nannofossils and Milankovitch cycles: the example of the Albian Gault Clay Formation (southern England). Palaeogeogr Palaeoclimatol 93:47-69

29. Erba E, Watkins D, Mutterlose J (1995) Campanian dwarf calcareous nannofossils from Wodejebato Gutyot. In: Haggerty JA, Premoli Silva I, Rack F, McNutt MK (eds) Proceedings of Ocean Drill Program. Sci Results 144:141-156

30. Eshet Y, Almogi-Labin A (1996) Calcareous nannofossils as paleoproductivity indicators in Upper Cretaceous organic-rich sequences in Israel. Mar Micropaleontol 29:37-61

31. Eshet Y, Moshkovitz S, Habib D, Benjamini C, Magaritz M (1992) Calcareous nannofossil and dinoflagellate stratigraphy across the Cretaceous/Tertiary boundary at Hor Hahar, Israel. Mar Micropaleontol 18:199-228

32. Fisher CG, Hay WW (1999) Calcareous nannofossils as indicators of Mid-Cretaceous paleofertility along an ocean front, U. S. Western Interior. In: Barrera E, Johnson CC (eds) Evolution of the Cretaceous ocean-climate system. Geol Soc Am 332:161-180

33. Friedrich O, Herrle JO, Hemleben C (2005) Climatic changes in the Late Campanian-Early Maastrichtian: micropaleontological and stable isotopic evidence from an epicontinental sea. $J$ Foramin Res 35:228-247

34. Friedrich O., Herrle J.O., Wilson P.A., Cooper M.J., Erbacher J., Hemleben C. (2009) Early Maastrichtian carbon cycle perturbation and cooling event: implications from the South Atlantic Ocean. Paleoceanography 24, PA2211. doi:10.1029/2008PA001654

35. Gardin S (2002) Late Maastrichtian to early Danian calcareous nannofossils at Elles (Northwest Tunisia). A tale of one million years across the $K-T$ boundary. Palaeogeogr Palaeoclimatol 178:211-231

36. Gardin S, Monechi S (1998) Palaeoecological change in middle to low latitude calcareous nannoplankton at the Cretaceous/Tertiary boundary. Bull Soc Geol Fr 169:709-723

37. Gardin S, Galbrun B, Thibault N, Coccioni R, Premoli-Silva I (2012) Bio-magnetochronology for the upper Campanian Maastrichtian from the Gubbio area, Italy: new results from the Contessa Highway and Bottaccione sections. News/ Stratigr 45:75-103

38. Grinsted A, Moore JC, Jevrejeva S (2004) Application of the cross wavelet transform and wavelet coherence to geophysical time series. Nonlinear Process Geophys 11:561-566

39. Grossman EL (2012) Chapter 10: oxygen isotope stratigraphy. In: Gradstein FM et al (eds) The geologic time scale 2012. Elsevier, Boston, pp 181-206

40. Hagelberg TK, Bond G, deMenocal P (1994) Milankovitch band forcing of sub-Milankovitch climate variability during the Pleistocene. Paleoceanography 9:545-558

41. Hardas $P$, Mutterlose $J$ (2007) Calcareous nannofossils assemblages of Oceanic Anoxic Event 2 in the equatorial Atlantic: evidence of an eutrophication event. Mar Micropaleontol 66:52-69

42. Hardas P, Mutterlose J, Friedrich O, Erbacher J (2012) The Middle Cenomanian Event in the equatorial Atlantic: the calcareous nannofossil and benthic foraminiferal response. Mar Micropaleontol 96-97:66-74

43. Hennebert M (2012) Hunting for the 405-kyr eccentricity cycle phase at the CretaceousPaleogene boundary in the Aïn Settara section (Kalaat Senan, central Tunisia). Carnets de Géologie [Notebooks on Geology], Brest, Article 2012/05 (CG2012_A05): 93-116

44. Henriksson AS (1993) Biochronology of the terminal Cretaceous calcareous nannofossil Zone of Micula prinsii. Cretac Res 14:59-68 
45. Herbert TD (1999) Toward a composite orbital chronology for the Late Cretaceous and Early Palaeocene GPTS. Philos Trans R Soc Lond A 357:1891-1905

46. Herbert TD, Premoli Silva I, Erba E, Fischer AG (1995) Orbital Chronology of CretaceousPaleocene marine sediments, in: Geochronology Time Scales and Global Stratigraphic Correlation, SEPM Spec Pub, pp 80-93

47. Hermoso M, Le Callonnec L, Minoletti F, Renard M, Hesselbo SP (2009) Expression of the Early Toarcian negative carbon-isotope excursion in separated carbonate microfractions (Jurassic, Paris Basin). Earth Planet Sci Lett 277:194-203

48. Hill ME (1975) Selective dissolution of Mid-Cretaceous (Cenomanian) Calcareous Nannofossils. Micropaleontology 21:227-235

49. Hinnov LA (2000) New perspectives on orbitally forced stratigraphy. Annu Rev Earth Planet Sci 28:419-475

50. Hull PM, Norris RD, Bralower TJ, Schueth JD (2011) A role for chance in marine recovery from the end-Cretaceous extinction. Nat Geosci 4:856-860

51. Husson D, Galbrun B, Laskar J, Hinnov LA, Thibault N, Gardin S, Locklair RE (2011) Astronomical calibration of the Maastrichtian (Late Cretaceous). Earth Planet Sci Lett 305:328-340

52. Husson D, Galbrun B, Gardin S, Thibault N (2014a) Tempo and duration of short-term environmental perturbations across the Cretaceous-Paleogene boundary. Stratigraphy (in press)

53. Husson D, Thibault N, Galbrun B, Gardin S, Minoletti F, Sageman B, Huret E (2014b) Lower Maastrichtian cyclostratigraphy of the Bidart section (Basque country, SW France): a remarkable record of precessional forcing. Palaeogeogr Palaeoclimatol 395:176-197

54. Jarvis I, Mabrouk A, Moody RTJ, de Cabrera S (2002) Late Cretaceous (Campanian) carbon isotope events, sea-level change and correlation of the Tethyan and Boreal realms. Palaeogeogr Palaeoclimatol 188:215-248

55. Jarvis I, Gale AS, Jenkyns HC, Pearce MA (2006) Secular variation in Late Cretaceous carbon isotopes: a new $\delta 13 \mathrm{C}$ carbonate reference curve for the Cenomanian-Campanian (99.6-70.6 Ma). Geol Mag 143:561-608

56. Jenkyns HC, Mutterlose J, Sliter WV (1995) Upper Cretaceous carbon- and oxygen isotope stratigraphy of deep-water sediments from the North-Central Pacific (Site 869, Flank of PikiniWodejebato, Marshall Islands). Proc ODP Sci Res 143:105-108

57. Jiang S, Bralower TJ, Patzkowsky ME, Kump LR, Schueth JD (2010) Geographic controls on nannoplankton extinction across the Cretaceous/Palaeogene boundary. Nat Geosci 3:280285

58. Jung C, Voigt S, Friedrich O, Koch MC, Frank M (2013) Campanian-Maastrichtian ocean circulation in the tropical Pacific. Paleoceanography 28:1-12. doi:10.1002/palo.20051

59. Keller G, Adatte T, Gardin S, Bartolini A, Bajpai S (2008) Main Deccan volcanism phase ends near the K-T boundary: evidence from the Krishna-Godavari Basin, SE India. Earth Planet Sci Lett 268:293-311

60. Keller G, Adatte T, Bhowmick P, Upadhyay H, Dave A, Reddy AN, Jaiprakash BC (2012) Nature and timing of extinctions in Cretaceous-Tertiary planktic foraminifera preserved in Deccan intertrappean sediments of the Krishna-Godavari Basin, India. Earth Planet Sci Lett 341-344:211-221

61. Kessels K, Mutterlose J, Michalzik D (2006) Early Cretaceous (Valanginian-Hauterivian) calcareous nannofossils and isotopes of the northern hemisphere: proxies for the understanding of Cretaceous climate. Lethaia 39:157-172

62. Kucera M, Malmgren BA (1998) Terminal Cretaceous warming event in the mid-latitude South Atlantic Ocean: evidence from poleward migration of Contusotruncana contusa (planktonic foraminifera) morphotypes. Palaeogeogr Palaeoclimatol 138:1-15 
63. Kuiper KF, Deino A, Hilgen FJ, Krijgsman W, Renne PR, Wijbrans JR (2008) Synchronizing rock clocks of earth history. Science 320:500-504

64. Kump LR, Arthur MA (1999) Interpreting carbon-isotope excursions: carbonates and organic matter. Chem Geol 161:181-198

65. Laskar J, Robutel P, Joutel F, Gastineau M, Correia A, Levrard B (2004) A long term numerical solution for the insolation quantities of the earth. Astron Astrophys 428:261-285

66. Lees JA (2002) Calcareous nannofossil biogeography illustrates palaeoclimate change in the Late Cretaceous Indian Ocean. Cretaceous Res 23:537-634

67. Lees JA, Bown PR, Mattioli E (2005) Problems with proxies? Cautionary tales of calcareous nannofossils paleoenvironmental indicators. Micropaleontology 51:333-343

68. Li L, Keller G (1998a) Abrupt deep-sea warming at the end of the Cretaceous. Geology 26:995-998

69. Li L, Keller G (1998b) Maastrichtian climate, productivity and faunal turnovers in planktic foraminifera in South Atlantic DSDP sites 525A and 21. Mar Micropaleontol 33:55-86

70. Li L, Keller G, Adatte T, Stinnesbeck W (2000) Late Cretaceous sea-level changes in Tunisia: a multi-disciplinary approach. J Geol Soc Lond 157:447-458

71. Linnert C, Mutterlose J (2009) Evidence of increasing surface water oligotrophy during the Campanian-Maastrichtian boundary interval: Calcareous nannofossils from DSDP Hole 390A (Blake Nose). Mar Micropaleontol 73:29-36

72. Linnert C, Mutterlose J, Erbacher J (2010) Calcareous nannofossils of the Cenomanian/Turonian boundary interval from the Boreal Realm (Wunstorf, northwest Germany). Mar Micropaleontol 74:38-58

73. Linnert C, Mutterlose J, Herrle JO (2011) Late Cretaceous (Cenomanian-Maastrichtian) calcareous nannofossils from Goban Spur (DSDP Sites 549, 551): Implications for the palaeoceanography of the proto North Atlantic. Palaeogeogr Palaeoclimatol 299:507-528

74. Maurer F, Hinnov LA, Schlager W (2004) Statistical time-series analysis and sedimentological tuning of bedding rhythms in a Triassic basinal succession (Southern Alps, Italy). In: D'Argenio $B$ et al (eds) Cyclostratigraphy: approaches and case histories, SEPM Spec Publ 81, pp 83-99

75. Minoletti F, de Rafélis M, Renard M, Gardin S (2004) Reworking of Maastrichtian-like calcareous nannofossils in the lowermost Danian sediments of Bidart section (France): isotopic evidence (carbon and oxygen). Rev Micropaléontol 47:145-152

76. Minoletti F, de Rafélis M, Renard M, Gardin S, Young J (2005) Changes in the pelagic fine fraction carbonate sedimentation during the Cretaceous-Paleocene transition: contributions of the separation technique to the study of Bidart section. Palaeogeogr Palaeoclimatol 216:119137

77. Mitchell SF, Ball JD, Crowley SF, Marshall JD, Paul CRC, Veltkamp CJ, Samir A (1997) Isotope data from cretaceous chalks and foraminifera: environmental or diagenetic signals? Geology 25:691-694

78. Molina E, Alegret L, Arenillas I, Arz JA, Gallala N, Hardenbol J, von Salis K, Steurbaut E, Vandenberghe N, Zaghbib-Turki D (2006) The Global Stratotype Section and Point for the base of the Danian stage (Paleocene, Paleogene, "Tertiary", Cenozoic) at El Kef, Tunisiaoriginal definition and revision. Episodes 29:263-273

79. Molina E, Alegret L, Arenillas I, Arz JA, Gallala N, Grajales-Nishimura JM, Murillo-Muñetón G, Zaghbib-Turki D (2009) The global stratotype section and point for the base of the Danian stage (Paleocene, Paleogene, "Tertiary", Cenozoic): auxiliary sections and correlations. Episodes 32:84-95

80. Moolna A, Rickaby REM (2012) Interaction of the coccolithophore Gephyrocapsa oceanica with its carbon environment: response to a recreated high- $\mathrm{CO}_{2}$ geological past. Geobiology 10:72-81 
81. Mutterlose J (1991) Das Verteilungs- und Migrationsmuster des kalkigen Nannoplanktons in der borealen Unterkreide (Valangin-Apt). Palaeontogr B 221:27-152

82. Mutterlose J (1992) Lower Cretaceous nannofossil biostratigraphy off northwestern Australia (Leg 123). In: Proceedings of Ocean Drill Program. Sci Results 123:343-368

83. Mutterlose J, Kessels K (2000) Early Cretaceous calcareous nannofossils from the high latitudes: implications for palaeobiogeography and palaeoclimate. Palaeogeogr Palaeoclimatol 160:347-372

84. Nordt LC, Atchley SC, Dworkin SI (2003) Terrestrial evidence for two greenhouse events in the latest Cretaceous. GSA today 13:4-9

85. Norris RD, Kroon $D$, Klaus $A$ et al (1998) Shipboard scientific party. Proc ODP Init Rep 171B:11-44

86. Olsson RK, Wright JD, Miller KG (2001) Paleobiogeography of Pseudotextularia Elegans During the Latest Maastrichtian global warming event. J Foramin Res 31:275-282

87. Pardo A, Ortiz N, Keller $G$ (1996) Latest Maastrichtian and K/T boundary foraminiferal turnover and environmental changes at Agost, Spain. In: MacLeod N, Keller G (eds) Biotic and environmental events across the Cretaceous/Tertiary boundary. GSA Spec Pap 307:139_ 171

88. Patterson RT, Fishbein E (1989) Re-examination of the statistical methods used to determine the number of point counts needed for micropaleontological quantitative research. $J$ Paleontol 63:245-248

89. Perch-Nielsen K (1985) Mesozoic calcareous nannofossils. In: Bolli HM et al (eds) Plankton stratigraphy. Cambridge University Press, Cambridge, pp 329-426

90. Perch-Nielsen K, McKenzie J, He Q (1982) Biostratigraphy and isotope stratigraphy and the 'catastrophic' extinction of calcareous nannoplankton at the Cretaceous/Tertiary boundary. In: Silver LT, Schultz $P$ (eds) Geological implications of impacts of large asteroids and comets on the Earth. GSA Spec Paper 190:353-371

91. Peypouquet JP, Grousset F, Mourguiart P (1986) Paleoceanography of the Mesogean Sea based on ostracods of the northern tunisian continental shelf between the Late Cretaceous and Early Paleogene. Geol Rundsch 75:159-174

92. Pospichal JJ (1996) Calcareous nannoplankton mass extinction at the Cretaceous/Tertiary boundary: An update. In: Ryder $G$ et al (eds) The Cretaceous-Tertiary event and other catastrophes in Earth history. GSA Spec Paper 307:335-360

93. Premoli Silva I, Erba E, Tornaghi ME (1989) Paleoenvironmental signals and changes in surface fertility in Mid Cretaceous Corg-Rich pelagic facies of the Fucoid Marls (Central Italy). Geobios 22:225-236

94. Punekar J, Mateo P, Keller G (2014) Effects of Deccan volcanism on paleoenvironment and planktic foraminifera: a global survey. In: Keller G, Kerr AC (eds) Volcanism, impacts, and mass extinctions: causes and effects. GSA Spec Pap 505:91-116

95. Renne PR, Deino AL, Hilgen FJ, Kuiper KF, Mark DF, Mitchell WS, Morgan LE, Mundil R, Smit $J$ (2013) Time scales of critical events around the Cretaceous-Paleogene boundary. Science 339:684-687

96. Reuning L, Reijmer JJG, Betzler C, Timmermann A, Steph S (2006) Sub-Milankovitch cycles in periplatform carbonates from the early Pliocene Great Bahama Bank. Paleoceanography 21:PA1017. doi:10.1029/2004PA001075

97. Rickaby REM, Henderiks J, Young JN (2010) Perturbing phytoplankton: response and isotopic fractionation with changing carbonate chemistry in two coccolithophore species. Clim Past 6:771-785

98. Robinson N, Ravizza G, Coccioni R, Peucker-Ehrenbrink B, Norris R (2009) A high-resolution marine 1870 s/188 Os record for the late Maastrichtian: distinguishing the chemical fingerprints of Deccan volcanism and the KP impact event. Earth Planet Sci Lett 281:159-168 
99. Rodriguez-Tovar FJ, Pardo-Iguzquiza E (2003) Strong evidence of high-frequency (subMilankovitch) orbital forcing by amplitude modulation of Milankovitch signals. Earth Planet Sci Lett 210:179-189

100. Roth PH, Krumbach KR (1986) Middle Cretaceous calcareous nannofossil biogeography and preservation in the Atlantic and Indian oceans: implications for paleoceanography. Mar Micropaleontol 10:235-266

101. Said $R$ (1978) Etude Stratigraphique et micropaléontologique du passage CrétacéTertiaire du synclinal d'Elles (Région Siliana-Sers), Tunisie centrale. Université Pierre et Marie Curie, Paris 6, France

102. Schoene B, Samperton KM, Eddy MP, Keller G, Adatte T, Bowring SA, Khadri SFR, Gertsch $B$ (2015) U-Pb geochronology of the Deccan Traps and relation to the endCretaceous mass extinction. Science 347(6218):182184. doi:10.1126/science.aaa0118

103. Schulte $P$ et al (2010) The Chicxulub asteroid impact and mass extinction at the Cretaceous-Paleogene boundary. Science 327:1214-1218

104. Schulz M, Mudelsee M (2002) REDFIT: estimating red-noise spectra directly from unevenly spaced paleoclimatic time series. Comput Geosci 28:421-426

105. Self S, Blake S, Sharma K, Widdowson M, Sephton S (2008) Sulfur and chlorine in Late Cretaceous Deccan magmas and eruptive gas release. Science 319:1654-1657

106. Sheldon E, Ineson J, Bown P (2010) Late Maastrichtian warming in the Boreal Realm: Calcareous nannofossil evidence from Denmark. Palaeogeogr Palaeoclimatol 295:55-75

107. Stinnesbeck W, Ifrim C, Salazar C (2012) The Last Cretaceous Ammonites in Latin America. Acta Palaeontol Pol 57:717-728

108. Stüben $D$ et al (2003) Late Maastrichtian paleoclimatic and paleoceanographic changes inferred from Sr/Ca ratio and stable isotopes. Palaeogeogr Palaeoclimatol 199:107127

109. Sun J, Huang $X$ (2006) Half-precessional cycles recorded in Chinese loess: response to low-latitude insolation forcing during the Last Interglaciation. Quat Sci Rev 25:1065-1072

110. Taner MT (2000) Attributes revisited. Technical Publication, Rock Solid Images, Houston. http://www.rocksolidimages.com/pdf/attrib_revisited.htm

111. Tantawy AAAM (2003) Calcareous nannofossil biostratigraphy and paleoecology of the Cretaceous-Tertiary transition in the central eastern desert of Egypt. Mar Micropaleontol 47:323-356

112. Tantawy AAAM (2008) Calcareous nannofossil biostratigraphy and paleoecology of the Cenomanian-Turonian transition in the Tarfaya Basin, southern Morocco. Cretaceous Res 29:995-1007

113. Thibault N, Gardin S (2006) Maastrichtian calcareous nannofossil biostratigraphy and paleoecology in the Equatorial Atlantic (Demerara Rise, ODP Leg $207 \mathrm{Hole} \mathrm{1258A).} \mathrm{Rev}$ Micropaléontol 49:199-214

114. Thibault N, Gardin S (2007) The late Maastrichtian nannofossil record of climate change in the South Atlantic DSDP Hole 525A. Mar Micropaleontol 65:163-184

115. Thibault N, Gardin $S$ (2010) The calcareous nannofossil response to the endCretaceous warm event in the Tropical Pacific. Palaeogeogr Palaeoclimatol 291:239-252

116. Thibault N, Harlou R, Schovsbo N, Schiøler P, Minoletti F, Galbrun B, Lauridsen BW, Sheldon E, Stemmerik L, Surlyk F (2012a) Upper Campanian-Maastrichtian nannofossil biostratigraphy and high-resolution carbon-isotope stratigraphy of the Danish Basin: towards a

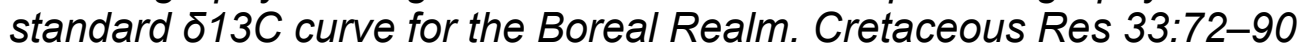

117. Thibault N, Husson D, Harlou R, Gardin S, Galbrun B, Huret E, Minoletti F (2012b) Astronomical calibration of upper Campanian-Maastrichtian carbon isotope events and calcareous plankton biostratigraphy in the Indian Ocean (ODP Hole 762C): implication for the age of the Campanian-Maastrichtian boundary. Palaeogeogr Palaeoclimatol 337-338:52-71 
118. Thierstein HR (1980) Selective dissolution of late cretaceous and earliest tertiary calcareous nannofossils: experimental evidence. Cretaceous Res 1:165-176

119. Thierstein HR (1981) Late Cretaceous nannoplankton and the change at the Cretaceous/Tertiary boundary. SEPM Spec Publ 32:355-394

120. Thomson DJ (1982) Spectrum estimation and harmonic analysis. Proc IEEE 70:10551096

121. Tiraboschi D, Erba E, Jenkyns HC (2009) Origin of rhythmic Albian black shales (Piobicco core, central Italy): Calcareous nannofossils quantitative and statistical analyses and paleoceanographic reconstructions. Paleoceanography. doi:10.1029/2008PA001670

122. Tobin TS, Ward PD, Steig EJ, Olivero EB, Hilburn IA, Mitchell RN, Diamond MR, Raub TD, Kirschvink JL (2012) Extinction patterns, $\delta 180$ trends, and magnetostratigraphy from a southern high-latitude Cretaceous-Paleogene section: links with Deccan volcanism. Palaeogeogr Palaeoclimatol 350-352:180-188

123. Tobin TS, Wilson GP, Eiler JM, Hartman JH (2014) Environmental change across a terrestrial Cretaceous-Paleogene boundary section in eastern Montana, USA, constrained by carbonate clumped isotope paleothermometry. Geology. doi:10.1130/G35262.1

124. Tuenter E, Weber SL, Hilgen FJ, Lourens LJ (2003) The response of the African summer monsoon to remote and local forcing due to precession and obliquity. Global Planet Change 36:219-235

125. Tuenter E, Weber SL, Hilgen FJ, Lourens LJ (2007) Simulating sub-Milankovitch climate variations associated with vegetation dynamics. Clim Past 3:169-180. doi:10.5194/cp3-169-2007

126. Voigt S, Gale AS, Jung C, Jenkyns HC (2012) Global correlation of Upper CampanianMaastrichtian successions using carbon-isotope stratigraphy: development of a new Maastrichtian timescale. Newslett Stratigr 45:25-53

127. Voigt S, Jung C, Friedrich O, Frank M, Teschner C, Hoffmann J (2013) Tectonically restricted deep-ocean circulation at the end of the Cretaceous greenhouse. Earth Planet Sci Lett 369-370:169-177

128. Ward PD (1990) A review of Maastrichtian ammonite ranges. In: Sharpton VL, Ward $P D$ (eds) Global catastrophes in earth history: an international conference on impacts, volcanism and mass mortality. GSA Spec Pap 247:519-530

129. Watkins DK, Self-Trail JM (2005) Calcareous nannofossil evidence for the existence of the Gulf Stream during the late Maastrichtian. Paleoceanography. doi:10.1029/ 2004PA001121

130. Watkins DK, Wise SW Jr, Pospichal JJ, Crux J (1996) Upper Cretaceous calcareous nannofossil biostratigraphy and paleoceanography of the Southern Ocean. In: Moguilevsky A, Whatley RC (eds) Microfossils and oceanic environments. University of Wales, AberystwythPress, United Kingdom, pp 355-381

131. Weedon GP (2003) Time-Series Analysis and Cyclostratigraphy. Cambridge University Press, Cambridge

132. Wendler I (2013) A critical evaluation of carbon isotope stratigraphy and biostratigraphic implications for Late Cretaceous global correlation. Earth Sci Rev 126:116146

133. Westerhold T, Röhl U, Raffi I, Fornaciari E, Monechi S, Reale V, Bowles J, Evans HF (2008) Astronomical calibration of the Paleocene time. Palaeogeogr Palaeoclimatol 257:377403

134. Wignall PB (2001) Large igneous provinces and mass extinctions. Earth Sci Rev 53:133 
135. Wilf $P$, Johnson KR, Huber BT (2003) Correlated terrestrial and marine evidence for global climate changes before mass extinction at the Cretaceous-Paleogene boundary. Proc Natl Acad Sci USA 100:599-604

136. Williams JR, Bralower TJ (1995) Nannofossil assemblages, fine fraction stable isotopes, and the paleoceanography of the Valanginian-Barremian (Early Cretaceous) North Sea Basin. Paleoceanography 10:815-839

137. Wu $H$, Zhang S, Feng Q, Jiang G, Li H, Yang $T$ (2012) Milankovitch and subMilankovitch cycles of the early Triassic Daye Formation, South China and their geochronological and paleoclimatic implications. Gondwana Res 22:748-759

138. Zaghbib-Turki D, Karoui-Yaakoub N, Rocchia R, Robin E, Belayouni H (2000) Enregistrement des événements remarquables de la limite Crétacé-Tertiaire dans la coupe d'Ellès (Tunisie). CR Acad Sci IIA 331:141-149 